Chicago-Kent College of Law

Scholarly Commons @ IIT Chicago-Kent College of Law

All Faculty Scholarship

Faculty Scholarship

February 1981

\title{
Lawyer Advertising and the First Amendment
}

Lori B. Andrews

IIT Chicago-Kent College of Law, landrews@kentlaw.iit.edu

Follow this and additional works at: https://scholarship.kentlaw.iit.edu/fac_schol

Part of the Legal Ethics and Professional Responsibility Commons

\section{Recommended Citation}

Lori B. Andrews, Lawyer Advertising and the First Amendment, 1981 Am. B. Found. Res. J. 967 (1981).

Available at: https://scholarship.kentlaw.iit.edu/fac_schol/15

This Article is brought to you for free and open access by the Faculty Scholarship at Scholarly Commons @ IIT Chicago-Kent College of Law. It has been accepted for inclusion in All Faculty Scholarship by an authorized administrator of Scholarly Commons @ IIT Chicago-Kent College of Law. For more information, please contact jwenger@kentlaw.iit.edu, ebarney@kentlaw.iit.edu. 


\title{
Lawyer Advertising and the First Amendment
}

\author{
Lori B. Andrews
}

\begin{abstract}
A current Supreme Court case concerning lawyer advertising, In re R.M.J., is analyzed in the context of a discussion of the diverse state regulations governing lawyer advertising and solicitation. The article considers the regulations in terms of their constitutionality, their tendency to impede effective advertising, and the effect they have on the legal profession's provision of information to potential clients about the nature, availability, and cost of legal services. Analysis of the major commercial speech cases, from Virginia State Board of Pharmacy to Central Hudson, indicates that many state rules infringe on attorneys' First Amendment rights.
\end{abstract}

\section{INTRODUCTION}

Canon 2 of the American Bar Association Model Code of Professional Responsibility says that "A lawyer should assist the legal profession in fulfilling its duty to make legal counsel available." But the disciplinary rules that have developed within Canon 2 have sometimes tended to hamper rather than to encourage lawyers in their attempts to fulfill that duty. In a series of cases in the past two decades, the U.S. Supreme Court has struck down as unconstitutional various aspects of the Canon 2 disciplinary rules (or state statutes comparable in language to the rules). In particular, the rules against advertising and solicitation have been found to have hindered lawyers in communicating to potential clients information that might help them make a decision about seeking legal services ${ }^{1}$ and in developing novel means of delivering legal services. ${ }^{2}$

Canon 2 disciplinary rules have come under attack in recent years because of the various provisions that prevent a lawyer from communicating information about the nature, identification, and cost of legal serv-

Lori B. Andrews is a Research Attorney at the American Bar Foundation. B.A., 1975, Yale College; J.D., 1978, Yale Law School.

1. Bates v. State Bar, 433 U.S. 350 (1977); In re Primus, 436 U.S. 412 (1978).

2. NAACP v. Button, 371 U.S. 415 (1963); Brotherhood of Railroad Trainmen v. Virginia ex rel. Virginia State Bar, 377 U.S. 1 (1964); United Mine Workers, Dist. 12 v. Illinois State Bar Ass'n, 389 U.S. 217 (1967); United Transp. Union v. State Bar, 401 U.S. 576 (1971). 
ices as well as about the lawyer's availability to perform those services. ${ }^{3}$ These provisions of Canon 2 were based on a rule adopted in 1908 as Canon 27 of the ABA Canons of Professional Ethics, which said that it was "unprofessional" for lawyers to advertise or solicit professional employment. ${ }^{4}$ So roundly disparaged were communications to potential clients that the ABA Standing Committee on Ethics and Professional Responsibility and state ethics committees across the country for decades closely scrutinized whether any contact by a lawyer with the publicfrom wearing jewelry with the word "Lawyer"s on it to participating in seminars to using a postage meter with the phrase "Ask a Lawyer" was an impermissible communication.

The 1908 ban was justified in part on the grounds that advertising and solicitation were unnecessary. At that time, most lawyers were general practitioners in small communities, and legal services were rendered in one-to-one relationships between people who knew each other in the community. It is within that context that a 1908 canon of ethics stated, "The most worthy and effective advertisement possible . . . is the establishment of a well-merited reputation for professional capacity and fidelity to trust." "7

As the century has unfolded, communities have grown in size, lawyers have become more specialized, and legal regulation has touched more aspects of daily life. Because of these changes, it became clear in the 1960s and 1970s that the total ban on lawyers' promotional communications to potential clients was not necessarily in the public interest. People were no longer able to find lawyers they needed by word of mouth alone. A national survey conducted by Barbara A. Curran of the American Bar Foundation in collaboration with the American Bar Association found that 83 percent of the public agreed with the statement that people do not go to lawyers because they have no way of knowing which lawyers are competent to handle their particular problems. ${ }^{8}$

The ban on lawyers' promotional activities also had a secondary effect of hampering the development of new means of delivering legal services.

3. See, e.g., Bates; Primus; Koffler v. Joint Bar Ass'n, 51 N.Y.2d 140, 412 N.E.2d 927, 432 N.Y.S.2d 872 (1980); Kentucky Bar Ass'n v. Stuart, 568 S.W.2d 933 (Ky. 1978); In re Jaques, 407 Mich. 26, 281 N.W.2d 469 (1979). But see Allison v. Louisiana State Bar Ass'n, 362 So. 2d 489 (La. 1978).

4. American Bar Association, Opinions of the Committee on Professional Ethics with the Canons of Professional Ethics Annotated and Canons of Judicial Ethics Annotated 75 (Chicago: American Bar Foundation, 1967).

5. The ABA Committee on Ethics and Professional Responsibility, in Informal Opinion 1342 (June $25,1975)$, found that the wearing of such jewelry did not constitute prohibited advertising.

6. ABA Informal Opinion 771 (Aug. 28, 1964) prohibited such a phrase in a postage meter imprint.

7. Supra note 4.

8. Barbara A. Curran, The Legal Needs of the Public: The Final Report of a National Survey 228 (Chicago: American Bar Foundation, 1977). 
Alternatives to traditional legal services such as prepaid legal service plans and legal clinics require a high volume of routine legal business to sustain themselves and to offer their unique benefits (spreading of risks or reasonable costs) to the public. ${ }^{9}$ However, that high volume of legal business cannot be generated unless lawyers can bring the particular legal service delivery mechanism to the public's attention through some sort of promotion.

In 1977, the U.S. Supreme Court in Bates v. State Bar of Arizona ${ }^{10}$ recognized these trends and held that lawyers have a constitutional right to advertise in print their prices for routine legal services. Since the Bates case, all states and the District of Columbia have adopted new ethics code rules to allow at least some promotional activities by attorneys. ${ }^{11}$ These

9. Project, An Assessment of Alternative Strategies for Increasing Access to Legal Services, 90 Yale L.J. 122, 129, 131 (1980).

10. 433 U.S. 350 (1977).

11. Code of Professional Responsibility of the Alabama State Bar as amended by Ala. Sup. Ct. Orders of May 10, 1978, and May 2, 1979; Alaska Code of Professional Responsibility as amended by Alaska Sup. Ct. Orders No. 356, Jan. 25, 1979, effective April 1, 1979, and No. 377, June 29, 1979, effective July 1, 1979; Arizona Code of Professional Responsibility, as amended by Ariz. Sup. Ct. Order of July 23, 1979, effective Nov. 1, 1979; Arkansas Code of Professional Responsibility and Canons of Judicial Ethics as amended by In re Amendments to the Code of Professional Responsibility and Canons of Judicial Ethics, 263 Ark. 948 (1978); Rules of Professional Conduct, Cal. Bus. \& Prof. Code foll. $\S 6076$, as amended by Cal. Sup. Ct. Order of Mar. 9, 1979, effective April 1, 1979 and resolution adopted by the Board of Governors of the State Bar of California of June 19, 1979; Colorado Code of Professional Responsibility, as amended by Colo. Sup. Ct. Order of Dec. 29, 1977, effective Jan. 2, 1978; Connecticut Code of Professional Responsibility, as amended by Conn. Super. Ct. Order of April 10, 1978, effective July 1, 1978, and by Conn. Super. Ct. Order of Mar. 30, 1979, effective July 1, 1979; Delaware Lawyer's Code of Professional Responsibility, as amended by Del. Sup. Ct. Order effective Nov. 22, 1977, and Del. Sup. Ct. Order of Aug. 15, 1979, effective Sept. 15, 1979; Code of Professional Responsibility and the Disciplinary Rules of the District of Columbia Court of Appeals, as amended by D.C. Ct. App. Order, effective July 12, 1978; Florida Bar Code of Professional Responsibility, as amended by Fla. Sup. Ct. Order, Case Nos. 55,263 and 54,925, of July 26, 1979; Rules and Regulations for the Organization and Government of the State Bar of Georgia, Ga. Sup. Ct. Order of May 12, 1978; Order Amending the Rules of the Supreme Court of the State of Hawaii, July 29, 1981; Code of Professional Responsibility of the State of Idaho, as amended by Idaho Sup. Ct. Order of May 25, 1978, effective July 1, 1978, and Idaho Sup. Ct. Order of, and effective, Feb. 23, 1979; Illinois Code of Professional Responsibility, adopted June 3, 1980, effective July 1, 1980; Indiana Rules of Professional Responsibility, as amended by Ind. Sup. Ct. Order of Dec. 14, 1977, effective January 1, 1978; Iowa Code of Professional Responsibility for Lawyers, as amended by Iowa Sup. Ct. Orders of Feb. 17, 1978, and May 6, 1980; Kansas Code of Professional Responsibility, Kan. Sup. Ct. Rule No. 225, as amended by Kan. Sup. Ct. Order effective Feb. 28, 1979; Ky. Sup. Ct. R. 3.135; Code of Professional Responsibility of the Louisiana State Bar Association, as amended by La. Sup. Ct. Order of Feb. 7, 1979, effective Dec. 1, 1979; Maine Bar Rules, as amended by Me. Sup. Jud. Ct. Order of May 1, 1979, effective May 15, 1979; Maryland Code of Professional Responsibility, Md. Rule 1230, as amended by Md. Ct. App. Rules Order of Mar. 8, 1978, effective May 1, 1978; Massachusetts Canons of Ethics and Disciplinary Rules Regulating the Practice of Law, as amended by Mass. Sup. Jud. Ct. Order of May 15, 1979, effective July 1, 1979; Mich. Sup. Ct. Orders effective Mar. 15, 1978, and Feb. 2, 1979; Minnesota Code of Professional Responsibilty, as amended by Minn. Sup. Ct. Order No. 46994, effective May 29, 1980; Mississippi Code of Professional Responsibility, as amended by Miss. Sup. Ct. Order of Sept. 19, 1977; Missouri Code of Professional Responsibility, Mo. Sup. Ct. Order of Oct. 24, 1977, effective January 1, 1978, and an Addendum to DR 2-101(B)(2) adopted by the Advisory Committee, Missouri Bar Administration, Nov. 18, 1977, effective Jan. 1, 1978; Montana Canons of Professional Ethics, as amended by Mont. Sup. Ct. Order 
recent amendments, which vary widely from state to state, regulate the permissible content, format, and media of lawyer advertising and solicitation. However, many of these state rules prohibit lawyers from communicating the type of information that the Bates Court (and various public surveys) found is most needed by the public. In addition, some state rules prohibit lawyers from using those particular advertising techniques that may be most effective, thus diminishing the incentive for attorneys to provide potential clients with information about the law, lawyers, and legal services.

This term, the U.S. Supreme Court will hear In re R.M.J., a case involving a lawyer who violated the post-Bates promotional rules adopted by the Missouri Supreme Court. The Missouri rules require that a lawyer limit the content of his or her advertising or other public communications to specific listed items of information. The rules also provide that an attorney who communicates to potential clients about the nature of his or her practice must use only the terms on an approved list of 23 categories. In addition, the rules provide that announcements of the opening of an

No. 12500, of June 24, 1980, effective July 1, 1980; Code of Professional Responsibility for Nebraska, as amended by Neb. Sup. Ct. Order of, and effective, May, 1979; Sup. Ct. R. 164, as amended by Nev. Sup. Ct. Order filed April 6, 1979, effective May 6, 1979; N.H. Code of Professional Responsibility, as amended by N.H. Sup. Ct. Order effective March 5, 1980, reprinted in 6 N.H.L. Weekly 429 (1980); Rules Governing the Courts of the State of New Jersey, as amended by N.J. Sup. Ct. Order of Jan. 26, 1979, effective April 1, 1979; N.M. Code of Professional Responsibility, amended by N.M. Sup. Ct. Order reprinted in 17 St. B.N.M. Bull. \& Advance Opinions 2481 (1978); 22 NYCRR Part 603, Conduct of Attorneys; N.C. Code of Professional Responsibility, as amended by N.C. Sup. Ct. Orders of Feb. 24, 1978, and Feb. 1979 (amendment to DR 2-102(C)); N.D. Code of Professional Responsibility, as amended by N.D. Sup. Ct. Order effective July 1, 1980; Ohio Code of Professional Responsibility, as amended by Ohio Sup. Ct. Orders effective Nov. 28, 1977, Mar. 13, 1978, Feb. 12, 1979, and June 11, 1979; Code of Professional Responsibility of the Oklahoma Bar Association, amended by Okla. Sup. Ct. Order of, and effective, Jan. 27, 1978; Oregon Code of Professional Responsibility, as amended by Or. Sup. Ct. Order of Jan. 9, 1979; Pennsylvania Code of Professional Responsibility, as amended by Pa. Sup. Ct. Orders of Jan. 16, 1979, June 29, 1979, and July 27, 1979; Supreme Court of the State of Rhode Island and Providence Plantations Provisional Order No. 11, entered Oct. 30, 1979; S.C. Code of Professional Responsibility, as amended by S.C. Sup. Ct. Order Re: Rules of Supreme Court, Rule 32, Code of Professional Responsibility, effective June 1, 1980; S.D. Code of Professional Responsibility, as amended by S.D. Sup. Ct. Order, of Oct. 23, 1979; Tennessee Code of Professional Responsibility, as amended by Tenn. Sup. Ct. Orders In re: Petition for Rule of Court Governing Lawyer Advertising, April 10, 1978, effective April 15, 1978, and In re: Petition of Disciplinary Board of the Supreme Court of Tennessee, Dec. 19, 1979; Rules Governing the State Bar of Texas, as amended by Tex. Sup. Ct. Order of Dec. 13, 1978; Utah Code of Professional Responsibility, as amended by Utah Sup. Ct. Order No. 16347, In re: Application to Allow Advertising by the Electronic Media, May 22, 1979; Vermont Code of Professional Responsibility, as amended by Vt. Sup. Ct. Order of July 15, 1977; Virginia Code of Professional Responsibility, as amended by Va. Sup. Ct. Order of Oct. 3, 1979, effective Jan. 1, 1980; Washington Code of Professional Responsibility, as amended by Wash. Sup. Ct. Order 25700-A-266, of Nov. 9, 1978, effective Jan. 1, 1979; W. Va. Code of Professional Responsibility, as amended by W. Va. Sup. Ct. App. Order of Oct. 18, 1978; Wisconsin Code of Professional Responsibility, as amended by Wis. Sup. Ct. Order of April 30, 1979; Wyoming Code of Professional Responsibility as amended by Wyo. Sup. Ct. Order effective Jan. 1, 1978. (Hereinafter, these rules will be referred to by state name.) 
office may be sent only to lawyers, clients, former clients, personal friends, and relatives.

The Missouri lawyer in the pending case advertised in print media the fact that he was a member of the Illinois, Missouri, and U.S. Supreme Court bars, which, though true, was not a permissible item for inclusion according to the Missouri advertising rule. In addition, he advertised the nature of his practice using terms that were not approved designations according to the official list; for example, he said that he practiced "Personal Injury" law rather than "Tort Law." He also sent promotional materials to two people he did not know. On the basis of these promotional activities, the Advisory Committee of the Missouri Bar filed an information in the Missouri Supreme Court seeking disbarment of the attorney. The court upheld the constitutionality of the Missouri rules and issued a private reprimand to the attorney.

This article puts in perspective the Missouri rules at issue in the R.M.J. case by describing both comparable and alternative rules for regulating lawyers' promotional activities in other states. It analyzes the lawyer advertising and solicitation rules of all 50.states and the District of Columbia in terms of their constitutionality, their tendency to impede effective advertising, and their effect on the legal profession's provision of information and services to potential clients.

\section{The Evolution of Commercial Speech Cases Affecting Professional AdVertising}

It is ironic that some of the rule amendments adopted since the Bates case, presumably to allow increased commercial communication from lawyer to potential client, are so restrictive that they would not allow the very ad at issue in Bates. ${ }^{12}$ One reason for the disparate, and sometimes restrictive, state rules governing lawyers' promotional activities may be a difficulty on the part of bar associations and courts in determining the appropriate level of constitutional protection to accord these activities. The recent U.S. Supreme Court cases regarding how professionals may communicate with potential customers or clients have dealt with regulations imposing a total ban on a certain type of speech or manner of communicating. The Court has generally rejected such total bans, yet has provided little guidance regarding the constitutionality of regulations that

12. See, e.g., Iowa DR 2-101. This is especially ironic in view of the fact that the Bates case has been characterized as placing a high value on consumer information. "The thrust of that [Bates] opinion is strongly in the direction of consumer information and away from the effect such advertising may have on professionalism." Lovett \& Linder, Ltd. v. Carter, C.A. No. 81-0118, at 19 (D.R.I. Sept. 8, 1981). "Bates is not a decision for the benefit of the bar; it is a decision for the benefit of consumers of legal services and it is from their viewpoint that the problem must be approached." Durham v. Brock, 498 F. Supp. 213, 222 (M.D. Tenn. 1980). 
allow some-but not all-types of truthful, nonmisleading, promotional communications by professionals. In addition, the Court has sent out conflicting signals regarding the level of scrutiny that commercial speech by professionals deserves.

In order to judge the constitutionality of those state advertising rules that have been adopted since Bates, it is necessary to review the recent evolution of the commercial speech doctrine. Commercial speech is protected by the First Amendment. "[C]ommercial speech serves to inform the public of the availability, nature, and prices of products and services, and thus performs an indispensable role in the allocation of resources in a free enterprise system," wrote Justice Blackmun for the majority in Bates. "The listener's interest is substantial: the consumer's concern for the free flow of commercial speech often may be far keener than his concern for urgent political dialogue."13

Despite its constitutional protection, regulations affecting commercial speech are subject to a lower level of constitutional scrutiny than those affecting other types of speech. There are two reasons for this. First, since commercial speakers know about their product or service, "they are well situated to evaluate the accuracy of their messages and the lawfulness of the underlying activity." 14 Thus there is not the same impetus to allow the publication of some false information as there is in the area of political speech, where protection of some false speech is thought necessary to encourage robust discussion. ${ }^{15}$ Second, because "advertising is the sine qua non of commercial profits, there is little likelihood of its being chilled by proper regulation and foregone entirely." 16

This lower level of constitutional scrutiny makes permissible certain types of regulations restricting commercial communications that might not be permitted regarding other types of speech. ${ }^{17}$ Still, because commercial speech contributes to enlightened decision making in a democra$\mathrm{cy},{ }^{18}$ it is protected to some degree. And in one important respect, the Court's approach to protection of commercial and other speech is the same: the content of the speech is more highly protected than its format

13. 433 U.S. at 364.

14. Central Hudson Gas \& Elec. Corp. v. Public Serv. Comm'n, 447 U.S. 557, 564 n.6 (1980), citing Bates v. State Bar, 433 U.S. 350, 381 (1977). See also Virginia State Bd. of Pharmacy v. Virginia Citizens Consumer Council, Inc., 425 U.S. 748, 772 n.24 (1976).

15. See, e.g. New York Times Co. v. Sullivan, 376 U.S. 254 (1964). See also Gertz v. Robert Welch, Inc., 418 U.S. 323, 341 (1974). ("The First Amendment requires that we protect some falsehood in order to protect speech that matters.")

16. Virginia State Bd. of Pharmacy v. Virginia Citizens Consumer Council, 425 U.S. at 772 n.24.

17. E.g., the U.S. Supreme Court in Bates, 433 U.S. at 380 , points out that "the justification for the application of overbreadth analysis applies weakly, if at all, in the ordinary commercial context." The attributes of commercial speech "may also make inapplicable the prohibition against prior restraints." Virginia State Bd. of Pharmacy, 425 U.S. at 772 n.24.

18. Virginia State Bd. of Pharmacy, 425 U.S. at 765. 
(that is, the time, place, and manner of the speech). With respect to commercial speech, the permissible content regulations include those that prohibit false and misleading speech ${ }^{19}$ or that prohibit speech advocating an illegal transaction. ${ }^{20}$ The permissible format regulations are those that are justified without reference to the content of the communication, serve a significant government interest, and in so doing leave open ample alternative channels for communication of the information. ${ }^{21}$

\section{A. Commercial Speech Cases Preceding Bates v. State Bar of Arizona}

The groundwork for considering the constitutional protection of promotional communications by lawyers was laid in a series of U.S. Supreme Court cases beginning in 1976. In Virginia State Board of Pharmacy $v$. Virginia Citizens Consumer Council, the Court considered a state regulation prohibiting pharmacists from advertising the prices of prescription drugs. ${ }^{22}$ The Court analyzed the content regulation involved, which was not aimed at false, fraudulent, or misleading speech or speech regarding any illegal transaction. The Court considered the reasons advanced to justify the ban, which had "to do principally with maintaining a high degree of professionalism on the part of licensed pharmacists." ${ }_{23}$ The Court acknowledged that assuring professionalism was a legitimate state interest. ${ }^{24}$ However, the Court concluded that a prohibition on speech (in this case, on advertising) could not be imposed to protect the ethical or performance standards of the profession. ${ }^{25}$

The test applied by the Court in Virginia State Board of Pharmacy has been characterized as a balancing test. ${ }^{26}$ However, if the language of the opinion suggests a weighing, it suggests one where, a priori, there is a thumb on the side of the scale representing speech, for faced with choosing between the state interests served by the regulation and the First Amendment interest at stake, the Court stated, "[T]he choice among these alternative approaches is not ours to make or the Virginia General Assembly's. It is precisely this kind of choice, between the dangers of

19. Bates, 433 U.S. at 383. The Court explains that the greater hardiness of commercial speech "may make it less necessary to tolerate inaccurate statements for fear of silencing the speaker."

20. Pittsburgh Press Co. v. Pittsburgh Comm'n on Human Relations, 413 U.S. 376 (1973).

21. See, e.g., Virginia State Bd. of Pharmacy, 425 U.S. at 771; Linmark Associates, Inc. v. Township of Willingboro, 431 U.S. 85 (1977); Koffler v. Joint Bar Ass'n, 51 N.Y.2d 140, 150, 412 N.E.2d 927, 934, 432 N.Y.S.2d 872, 878 (1980), cert. denied, 101 S. Ct. 1733 (1981); Lovett \& Linder, Ltd. v. Carter, C.A. No. 81-0118, at 17 (D.R.I., Sept. 8, 1981).

22. 425 U.S. 748 (1976).

23. Id. at 766 .

24. Id.

25. This summary of Virginia Pharmacy is found in Central Hudson Gas \& Elec. Corp. v. Public Serv. Comm'n, 447 U.S. 557, 564-65 (1980).

26. See, e.g., Note, Attorney Advertising Over the Broadcast Media, 32 Vand. L. Rev. 755,760 (1979); Note, Three Years Later: State Court Interpretations of the Attorney's Right to Advertise and the Public's Right to Information, 45 Mo. L. Rev. 562, 564 n.17 (1980). 
suppressing information, and the dangers of its misuse if it is freely available, that the First Amendment makes for us."27

The Virginia State Board of Pharmacy approach was followed in Linmark Associates, Inc. v. Township of Willingboro, ${ }^{28}$ where the Court struck down a municipal ordinance that prohibited the posting of "For Sale" or "Sold" signs on residential property. The Court in Linmark held that despite the ordinance's laudable purpose of preventing white flight, the government may not deny citizens commercial information that is neither false nor misleading. ${ }^{29}$

The municipality tried to argue that the ordinance should be judged not under the higher standard of a content regulation but rather as a reasonable format regulation. The Court rejected this argument on the theory that since the statute prohibited realty advertising only, it was directed to the content of the advertisements, rather than their time, place, or manner. In addition, the Court indicated that the regulation would not have been sustained even under the lower level of scrutiny required of a format regulation since there were "serious" 30 questions whether there were "ample alternative channels for communication" ${ }^{31}$ of the realty advertisements.

In its next commercial speech case, Carey v. Population Services International, ${ }^{32}$ the U.S. Supreme Court struck down a New York statute that prohibited the advertisement or display of contraceptives. The state had tried to justify the ban by saying that such advertisements would be offensive and embarrassing to their audience and would legitimize young people's sexual activities. The Court held that "the fact that protected speech may be offensive to some does not justify its suppression." ${ }^{33}$ The Court also reasserted its belief that the content of speech should be highly protected by noting that the state's arguments were "clearly directed not at any commercial aspect of the prohibited advertising but at the ideas conveyed and the form of expression-the core First Amendment values." 34

27. Virginia State Bd. of Pharmacy, 425 U.S. at 770.

28. 431 U.S. 85 (1977).

29. On that point, the Court, id. at 97, quoted the language in Virginia State Bd. of Pharmacy, 425 U.S. at 770, that "It is precisely this kind of choice, between the dangers of suppressing information, and the dangers of its misuse if it is freely available, that the First Amendment makes for us."

30. Id. at 93 .

31. Id.

32. 431 U.S. 678 (1977).

33. Id. at 701 .

34. Id. at 701 n.28. On this point, the Court cited Linmark Associates, Inc. v. Willingboro, 431 U.S. at $96-97$. 


\section{B. The Professional Promotion Cases}

In overruling the ban on advertising of drug prices by pharmacists in Virginia State Board of Pharmacy, the U.S. Supreme Court noted in dicta that advertising by lawyers might give rise to different considerations. Lawyers, said the Court, "do not dispense standardized products; they render professional services of almost infinite variety and nature, with the consequent enhanced possibility for confusion and deception if they were to undertake certain kinds of advertising." 35

A year later, when the Court was faced squarely with the issue of lawyer advertising in Bates $v$. State Bar of Arizona ${ }^{36}$ the majority referred in a footnote ${ }^{37}$ to this quote but did not articulate what differences existed between professional service advertising and product advertising and whether these differences should affect the standards by which the various types of commercial speech are judged. In fact, the majority seemed to imply that there was no relevant difference, saying that the results in the Bates case might be said to flow a fortiori from Virginia State Board of Pharmacy. ${ }^{38}$

The Bates Court felt that the public's need for information about the availability and terms of legal services outweighed the concerns the Arizona Bar Association expressed: namely, that advertising would have an adverse effect on professionalism, the quality of services, and the administration of justice; that it would be inherently misleading and have undesirable economic effects; and that it would create difficulties in enforcement. The Court recognized that an occasional client, not appreciating the complexity of his or her problem, might mistakenly believe it could be handled at the advertised price. However, that mistaken belief could be cleared up at the initial consultation and a fee then negotiated in the normal manner. "The client is thus in largely the same position as he would be if there were no advertising," wrote the Court. "In light of the benefits of advertising to those whose problem can be resolved at the advertised price, suppression is not warranted on account of the occasional client who misperceives his legal difficulties." 40

The Court held that lawyers' advertising could be subject to some regulations-namely, those it had approved for product advertising in Vir-

35. 425 U.S. at 773 n.25.

36. 433 U.S. 350 (1977).

37. Id. at 365-66 n.17.

38. Id. at 365. Justice Rehnquist had already pointed out in his dissent in Virginia State Bd. of Pharmacy, 425 U.S. at 785, that "if the sole limitation on permissible state proscription of advertising is that it may not be false or misleading, surely the difference between pharmacists' advertising and lawyers' and doctors' advertising can be only one of degree and not of kind."

39. Bates, 433 U.S. at 373 n.28.

40. Id. 
ginia State Board of Pharmacy. ${ }^{41}$ The Court said that false, fraudulent, and misleading advertising could be restricted and, to that end, the Court felt that a warning or disclaimer might be required in a price advertisement in order to assure that the consumer not be misled. ${ }^{42}$ In addition, the Court reiterated that the time, place, and manner of lawyer advertising, like that of other commercial speech, could be subject to reasonable restrictions. ${ }^{43}$ The Court also noted that "special problems of advertising on the electronic broadcast media will warrant special consideration." 44 reserved for future consideration the issues raised by advertisements about the quality of legal services ${ }^{45}$ and the promotion of services through in-person solicitation. ${ }^{46}$

While Bates dealt with advertising through the mass media, a year later the Court heard Ohralik v. Ohio State Bar Association, ${ }^{47}$ involving a lawyer's promotion of legal services in more personalized ways. ${ }^{48}$ Ohralik had been indefinitely suspended from practice for soliciting employment from two young accident victims, one of whom was in traction in a hospital at the time. The lawyer used a concealed tape recorder to record his conversations with both women, and when the first tried to dismiss him and then settled her suit, he sued her for breach of contract. Both women complained to disciplinary authorities about him. Ohralik argued that his speech was protected under the First and Fourteenth Amendments. ${ }^{49}$

The dangers that traditionally have been thought to justify a ban on attorney solicitation are the stirring up of litigation and fraudulent claims, the debasing of the legal profession, and the potential harm due to overreaching, overcharging, underrepresentation, and misrepresentation..$^{50}$

41. 425 U.S. at 771-73.

42. 433 U.S. at 384.

43. Id.

44. Id.

45. Id. at 383 .

46. Id. at 384 .

47. 436 U.S. 447, 457 (1978), rehearing denied, 439 U.S. 883.

48. In the same term, the Court also heard In re Primus, 436 U.S. 412 (1978), involving a lawyer's mailing to a potential client. At issue was the disciplinary rule prohibiting solicitation by lawyers. However, since the lawyer was offering the letter's recipient free legal representation by the American Civil Liberties Union, the Court analyzed the case not as a commercial speech case but as a political speech case. The Court said that "[t]his was not in-person solicitation for pecuniary gain" (id. at 422) and noted that for the ACLU "'litigation is not a technique of resolving private differences'; it is 'a form of political expression' and 'political association."' Id. at 428 (citations omitted).

The Court in Primus held that the ACLU attorney's activities were constitutionally protected since "[w]here political expression or association is at issue, this Court has not tolerated the degree of imprecision that often characterizes government regulation of the conduct of commercial affairs." Id. at 434. The Court held that in a political speech case, a state could prohibit solicitation only by narrowly drawn rules and only if the solicitation in fact were false, misleading, overbearing, deceptive, or if it invaded privacy or improperly influenced. Id. at 438.

49. 436 U.S. at 453.

50. Id. at 461 . 
However, a number of these alleged dangers are under attack as inappropriate bases for a prohibition. ${ }^{51}$ Moreover, other than the problem of overreaching, these problems do not seem inherently more common with solicitation than with advertising or even than with the traditional lawyerclient relationship.

The Supreme Court in Ohralik did not analyze whether these traditional concerns were in fact related to solicitation or whether they provided an adequate rationale for the state regulation of lawyer solicitation. Instead, since Ohralik had conceded and the Supreme Court agreed that states have a legitimate interest in preventing those aspects of solicitation that involve fraud, undue influence, intimidation, overreaching, and other forms of "vexatious conduct," 52 the Court analyzed the constitutionality of the Ohio disciplinary rule in those terms.

Crucial to the Court's analysis was the distinction it saw between advertising and an in-person contact by an attorney motivated by pecuniary gain. First, in-person solicitation might not facilitate informed and reliable decision making. "Unlike a public advertisement, which simply provides information and leaves the recipient free to act upon it or ${ }^{\mathrm{i}} i$, inperson solicitation may exert pressure and often demands an immediate response, without providing an opportunity for comparison or reflection." "In particular, "there is no opportunity for intervention or counter-education by agencies of the Bar, supervising authorities, or persons close to the solicited individual." "54 Second, even if the soliciting lawyer were well-meaning, the communication might be harmful purely because of its obtrusiveness and the invasion of the individual's privacy. ${ }^{55}$ Third, in-person solicitation is more difficult to monitor than advertising since it "is not visible or otherwise open to public scrutiny." "56

All these concerns are based on the time, place, and manner of attorney solicitation. Yet, instead of following the approach it had articulated earlier in commercial speech cases of being highly protective of the content (or pure speech aspect) of the communication while allowing more intrusive regulation of the time, place, and manner (nonspeech aspects of the communication), the Ohralik Court did not even allude to past decisions on or the traditional standards for time, place, and manner regulation. Instead the Court created a rule that would apply to both the content and the format of in-person communication. The Court held in Ohralik that a

51. See, e.g., Comment, A Critical Analysis of Rules Against Solicitation by Lawyers, 25 U. Chi. L. Rev. 674 (1958); Comment, Advertising, Solicitation and the Profession's Duty to Make Legal Counsel Available, 81 Yale L.J. 1181 (1972).

52. 436 U.S. at 462.

53. Id. at 457 .

54. Id.

55. Id.

56. Id. at 466. 
prophylactic regulation was appropriate to protect the lay public from the potential dangers of in-person solicitation for pecuniary gain that was likely to be deceptive, fraudulent, overreaching, unduly influential or intimidating, or to result in other forms of vexatious conduct. ${ }^{37}$ The Court tried to justify its unusual rule by creating an entirely new category of speech for in-person solicitation and subjecting it to a lower level of scrutiny.

"In-person solicitation by a lawyer of remunerative employment is a business transaction in which speech is an essential but subordinate component," wrote the Court. "While this does not remove the speech from the protection of the First Amendment, as was held in Bates and Virginia Pharmacy, it lowers the level of appropriate judicial scrutiny." "s8 However, the rationale for the creation of this third level of scrutiny is not convincing since there is no inherent difference in content between advertising and in-person communications.

Clearly, the value that the Bates Court found in commercial speech (that it "serves to inform the public of the availability, nature, and prices of products and services, and thus performs an indispensable role in the allocation of resources in a free enterprise system' $)^{59}$ are found equally in lawyers' communications in the mass media and lawyers' personalized communications. In fact, the Court pointed out that in-person solicitation apprised clients "of their legal rights and of the availability of a lawyer to pursue their claims," which was the function served by the advertisement at issue in Bates ${ }^{60}$ Both mass media and personalized contacts attempt to convince the "audience" (be it the reader of a newspaper or the recipient of a lawyer's letter or in-person communication) to hire the attorney. Thus, the content of a lawyer's speech, whether the communication is delivered via advertising or in-person contact, should be subject to a single standard of regulation, such as a prohibition on speech that is false, fraudulent, or misleading.

What distinguishes the personalized approach from the mass media approach is not its content but the potential for abuse due to the time, place, and manner of the communication. If the Court had based its analysis on that fact, it would not have had to establish for in-person solicitation an entirely new commercial speech standard lower than that

57. Id. at 449 .

58. Id. at 457. The Court stressed this by saying "in-person solicitation of professional employment by a lawyer does not stand on a par with truthful advertising about the availability and terms of routine legal services, let alone with the forms of speech more traditionally within the concern of the First Amendment." Id. at 455.

59. Bates, 433 U.S. at 364.

60. 436 U.S. at 455 . The attorney in Ohralik had provided the two women he contacted with useful information. He had told them, for example, that even though their car had been hit by an uninsured motorist, they could collect for their injuries under the policy covering their car. 
governing commercial speech through advertising. It could have applied the standards it set forth in Bates allowing the prohibition of false and misleading commercial speech by lawyers and allowing a reasonable regulation of time, place, and manner of the promotion.

The decision in Ohralik would have been more in keeping with other commercial speech cases if it had applied a two-level regulatory approach, regulating the content of speech if it were actually false, fraudulent, or misleading and the format of the speech if it were likely to be overbearing, to unduly influence, or to invade privacy, rather than regulating both content and format under the "likely to be" criterion. ${ }^{61}$ Such a standard would still have led to Ohralik being disciplined (because of the potential for harm due to the time, place, and manner in which he solicited), ${ }^{62}$ yet would be more consistent with previous First Amendment decisions than was the standard articulated in Ohralik.

\section{Commercial Speech Cases Since the Lawyers' Promotion of Services Cases}

Unlike its approach in the lawyer advertising and solicitation cases, the U.S. Supreme Court in its next professional service case, Friedman $v$. Rogers ${ }^{63}$ at least attempted to articulate general commercial speech standards in justifying its decision. In this case, however, the Court made a questionable interpretation of facts in applying the standards.

Friedman $v$. Rogers involved a Texas statute prohibiting optometrists from practicing under a trade name. N. Jay Rogers, the optometrist challenging the rule, had interests in 82 optometrical shops, all of which operated under the trade name "Texas State Optical" or "Tso."

The district court that heard the case had found that the trade name Tso had come to signify certain standards of price, quality, and availability to the public. It therefore held that the restriction against trade names was an unconstitutional restriction of the "free flow of commercial information." "64

The district court appears to have struck down the restriction because

61. Justice Marshall, concurring in Ohralik, proposed a standard that would be even more protective of personalized promotion than either the majority's standard or the one I am proposing. Justice Marshall felt "The First Amendment informational interests served by solicitation, whether or not it occurs in a purely commercial context, are substantial, and they are entited to as much protection as the interests we found to be protected in Bates." Ohralik, 436 U.S. at 474 (Marshall, J., concurring). From his perspective, a greater restriction on in-person solicitation could be justified "only to the degree that dangers which the State has a right to prevent are actually presented by conduct attendant to such speech, thus increasing the relative 'strength of the State's countervailing interest in prohibition," 'id. at 477. Marshall was able to concur in Ohralik because he felt that the attorney's behavior did present actual danger.

62. See text at notes 56-58 supra.

63. 440 U.S. 1 (1979).

64. Rogers v. Friedman, 438 F. Supp. 428, 431 (E.D. Tex. 1977). 
it was not directed at false, deceptive, or misleading speech. However, the U.S. Supreme Court did not uphold this ruling. In analyzing the case, the Court reiterated that the permissible types of regulation were those mentioned in Virginia State Board of Pharmacy and Bates-restrictions on false, deceptive, and misleading speech as well as reasonable regulations on format.

Despite its articulation of these traditional tests, the Court apparently gave no protection at all to trade names because of its belief that trade names were "a form of commercial speech that has no intrinsic meaning." 65 This finding itself is questionable since, as one commentator points out, no speech has intrinsic meaning until its use associates a meaning with it. ${ }^{66}$ But even more questionable is the ready inference that as a trade name does develop meaning, it will be put to a harmful rather than a helpful use. ${ }^{67}$

The Court appears to have passed over information about the value of trade names that was presented in a deposition in the case by economist Lee Kenneth Benham. Benham testified that in our mobile society, trade names permit consumers "to locate the goods, services, and prices they prefer on a continuing basis with substantially lower search costs than would otherwise be the case." $68 \mathrm{He}$ also pointed out that the use of a trade name may lead to enhanced rather than diminished quality of services: "[F]irms have an enormous incentive to develop and maintain the integrity of the products and services provided under their trade name: the entire package they offer is being judged continuously by consumers on the basis of the samples they purchase." 69

The Court also seems to overestimate the public's naivete by saying that the use of a trade name could give the impression that Rogers or one of his brothers was practicing in each of the 82 offices. ${ }^{70}$ This is akin to assuming that clients who go into the Cravath, Swaine \& Moore law office in New York might believe they would get to speak to (the long-departed) Mr. Cravath ${ }^{71}$ or that customers who buy a hamburger at the Golden Arches may expect to be served by Mr. MacDonald.

65. Friedman v. Rogers, 440 U.S. at 12.

66. Wesley J. Liebeler, The Essence of Chaos: The Supreme Court, Advertising and the First Amendment, Wash. St. B. News, Feb. 1980, at 14, 23.

67. The fact that the Court views trade names as undoubtedly harmful is shown by the statement that "Texas has done no more than require that commercial information about optometrical services 'appear in such a form . . . as [is] necessary to prevent its being deceptive." ' Friedman v. Rogers, 440 U.S. at 16, quoting Virginia State Bd. of Pharmacy, 425 U.S. at 772 n.24.

68. Friedman v. Rogers, 440 U.S. at 22 (Blackmun, J., and Marshall, J., concurring in part and dissenting in part).

69. Id. at $22-23$.

70. Id. at 14.

71. It is interesting to note that the Texas act had no requirement that the name of all partners be used to identify an optometric office; under the Court's logic, then, the public might be misled into thinking the only optometrists in the office were those whose names were part of the office name. 
The Court expressed concern about the problems that would ensue if trade names were used and developed meanings: continued use of a trade name after the departure of the optometrist whose reputation or skill attracted people to the office, assumption of a new trade name by an optometrist who was negligent or guilty of misconduct, in order to conceal his identify, and a false appearance of competition among shops of common ownership operating under different trade names.

But even if one accepts that parade of horribles, all of them could be chased away by a requirement that the practicing optometrist's name be communicated along with the trade name (e.g., on signs or in advertisements). In fact, the Court noted that under the Federal Trade Commission Act, the FTC cannot prohibit the use of a deceptive or misleading trade name if the defect can be cured by requiring that additional information be communicated. The Court rejected such an approach in the Friedman case on the ground that "there is no First Amendment rule, comparable to the limitation on $\S 5$ [of the Federal Trade Commission Act], requiring a State to allow deceptive or misleading commercial speech whenever the publication of additional information can clarify or offset the effects of the spurious communication." 72

However, it is exactly that sort of rule that the Court advocated in earlier commercial speech cases, including Bates. In Linmark, the Court had pointed to the First Amendment tradition where "the remedy to be applied is more speech, not enforced silence." 73 Similarly, in Bates, the Court had pointed out that any inaccurate picture caused by advertising could be cleared up by more information: "If the naivete of the public will cause advertising by attorneys to be misleading, then it is the bar's role to assure that the populace is sufficiently informed as to enable it to place advertising in its proper perspective." 74 The Court evaded these precedents with its sleight of hand in declaring that trade names were meaningless (thus apparently providing nothing for the First Amendment to protect).

An additional grave shortcoming of the Friedman case is that the Court upholds a regulation on speech in order to undermine a particular type of commercial activity. The Court looks down on the commercial practice of optometry, which involves advertising and standardized services. ${ }^{75}$ In fact, the Court makes the remarkable statement that the "use of

72. Friedman v. Rogers, 440 U.S. at 12 n.11.

73. Linmark Associates, Inc. v. Township of Willingboro, 431 U.S. at 97, quoting Whitney v. California, 274 U.S. 357, 377 (1927) (Brandeis, J., concurring).

74. Bates, 433 U.S. at 375.

75. The Court does so despite economic surveys showing the great benefits to the public of such an approach. A 1972 study of eyeglass prices, which controlled for factors such as quality, found that the average price for a pair of glasses in states that allowed eyeglass price advertising was $\$ 6.70$ lower than the price in states that prohibited it. Lee Benham, The Effect of Advertising on the Price 
a trade name also facilitates the advertising essential to large-scale commercial practices with numerous branch offices, conduct the State rationally may wish to discourage while not prohibiting . . . altogether."76 But restrictions on speech, even on the less-well-protected commercial speech, are not justifiable merely because they advance a particular policy that the state could have chosen to advance directly. Moreover, the very practice that the state was trying to discourage - the use of standardized, commercial professional services-was one the Court tacitly approved of in Bates, where the advertising was being done by a legal clinic that offered standardized, routine professional services. The Bates Court had stated that "Even if advertising leads to the creation of 'legal clinics' like that of appellants'-clinics that emphasize standardized procedures for routine problems-it is possible that such clinics will improve service by reducing the likelihood of error."77

The Court's fluctuating rationales in the cases from Bates through Friedman, coupled with the de minimis protection given trade names in the Friedman case, has subjected the Court to criticism for its " $a d$ hoc" approach. ${ }^{78}$ One commentator has suggested that "If we have a different level of First Amendment protection for 'political speech' than we do for 'commercial speech' and, in addition, different levels of such protection for different types of 'commercial speech,' there is nothing to prevent the Court from deciding these cases in a wholly arbitrary manner, as has, indeed, been pretty much the case so far." 79 Other commentators have pointed to the difficulty the Court has created in requiring a balancing without specifying what should be weighed. ${ }^{80}$

Last term, almost as if in response to such criticisms, the U.S. Supreme Court, in Central Hudson v. Public Service Commission, ${ }^{81}$ made its first attempt to provide comprehensive commercial speech guidelines based on both the product promotion and services promotion cases. Remarkably, in the course of discussing its standards, the Court cites Virginia State Board of Pharmacy, Linmark, Carey, Bates, Primus, Ohralik, and Fried-

of Eyeglasses, 15 J.L. \& Econ. 337 (1972). A study of retail drugs also found lower prices in states where advertising was allowed. Cady, Advertising Restrictions and Retail Prices, 16 J. Advertising Research 27 (1976).

76. Friedman v. Rogers, 440 U.S. at 13.

77. Bates, 433 U.S. at $378-79$.

78. In re R.M.J., 609 S.W.2d 411, 412 (Mo. 1981).

79. Liebeler, supra note 66 , at 22.

80. Note, Attorney Advertising Over the Broadcast Media, 32 Vand. L. Rev. 755, 756 (1979); Comment, Regulating Commercial Speech: A Conceptual Framework for Analysis, 32 Baylor L. Rev. 235, 236 (1980). The court in Durham v. Brock, 498 F. Supp. 213, 219 (M.D. Tenn. 1980), also points out: "The court did not make clear the test employed to find that the Bates ad was not false or misleading or the standards against which it was held" (footnote omitted).

81. 447 U.S. 557 (1980). 
man as if they formed a coherent body of commercial speech law, without making reference to the swings in theory in the more recent cases.

The Central Hudson case dealt with an order of the New York State Public Service Commission requiring that all electric utilities in the state stop promoting the use of electricity. Central Hudson Gas and Electric Corporation challenged the order, and the U.S. Supreme Court held it unconstitutional. In a seeming reversal from its paternalistic stance in Friedman, the Court cited the Linmark language: "[P]eople will perceive their own best interests if only they are wellenough informed, and . . . the best means to that end is to open the channels of communication rather than to close them." ${ }_{82}$ The Court went on to state, "Even when advertising communicates only an incomplete version of the relevant facts, the First Amendment presumes that some accurate information is better than no information at all.""83

In Central Hudson, the Court summarized its approach for dealing with commercial speech cases as follows:

In commercial speech cases, then, a four-part analysis has developed. At the outset, we must determine whether the expression is protected by the First Amendment. For commercial speech to come within that provision, it at least must concern lawful activity and not be misleading. Next, we ask whether the asserted governmental interest is substantial. If both inquiries yield positive answers, we must determine whether the regulation directly advances the governmental interest asserted, and whether it is not more extensive than is necessary to serve that interest. ${ }^{84}$

In the Central Hudson case, the Court applied its four-part test and found that speech promoting the use of electricity was not misleading or related to an unlawful act, that the government interest in encouraging energy conservation was substantial, and that the regulation advanced that government interest. However, the Court struck down the regulation because it was too broad to accomplish its specific purpose. In particular, the regulation would have prevented utilities from promoting electrical service that would have reduced energy by diverting demand from less efficient sources. ${ }^{85}$ Interestingly, the Court put the burden on the state to prove that it could not have come up with a less restrictive alternative, rather than on the party challenging the regulation to show that such an alternative existed. ${ }^{86}$

Central Hudson provides a much-needed coherent theory by which to

82. Id. at 562, quoting Linmark Associates Inc. v. Township of Willingboro, 431 U.S. 85, 92 (1977).

83. Id., citing Bates, 433 U.S. at 374.

84. $I d$. at 566 .

85. Id. at 570 .

86. Id. at 571 . 
judge the constitutionality of regulations on the content of commercial speech. It favors commercial speech as did Virginia State Board of Pharmacy and its progeny, cases that held that the choice between suppressing and allowing the publication of commercial information that could potentially be misused is made by the First Amendment. It fleshes out what a proper balancing, such as that required by Bates, would entail. Moreover, the least-restrictive-alternative part of the test would appear to leave room for avoiding the troublesome aspects of Ohralik by protecting the content of a solicitation unless it was in fact false or misleading. ${ }^{87}$

Although Central Hudson provides a standard by which to judge the constitutionality of regulations on commercial speech, some courts may be reluctant to apply Central Hudson to advertising and solicitation rules, possibly because of the confusion the Court has created with its multiple approaches to commercial speech in the past. ${ }^{88}$ In the R.M.J. case, for example, the Missouri Supreme Court expressed its frustration at the apparent lack of consistency in the U.S. Supreme Court's commercial speech decisions. When it was asked to apply the Central Hudson standards to the rules at issue, the Missouri Supreme Court stated, "We are urged now by respondent to follow the Central Hudson model. We respectfully decline to enter the thicket of attempting to anticipate and to satisfy the subjective ad hoc judgments of a majority of the justices of the United States Supreme Court." 89

The Missouri Supreme Court adopted an unnecessarily cavalier atti-

87. The use of the least restrictive alternative has practical benefits as well. "If the rules are unnecessary in terms of the court's consumer protection objectives, they may actually be counterproductive in terms of the delivery of legal services objective [i.e., assuring access of people to lawyers]. Also, unnecessary rules may result in unnecessary enforcement expense." Lawrence K. Hellman, The Oklahoma Supreme Court's New Rules on Lawyer Advertising: Some Practical, Legal, and Policy Questions, 31 Okla. L. Rev. 509, 527 (1978). Hellman advocates that the limited resources set aside for code enforcement "should be conserved to deal with violations that threaten or actually result in abuses of clients." Id. at 565.

88. In other instances, courts that have attempted to apply Central Hudson have done so incorrectly. The U.S. District Court for the Southern District of Iowa, in Bishop v. Committee on Professional Ethics \& Conduct, Civ. No. 81-47-D, at 11 (S.D. Iowa, Aug. 20, 1981), e.g., quotes the Central Hudson statement, 447 U.S. at 563, that the "government may ban forms of communication more likely to deceive the public than to inform it." In making that statement, the U.S. Supreme Court in Central Hudson had cited two cases where the communication at issue was not held to be as highly protected as was lawyer advertising-namely, Friedman, dealing with trade names, and Ohralik, dealing with in-person solicitation. These were both cases where a particular form of communication, not the content, was at issue. However, the lowa district court erroneously uses this standard in its analysis of content rules and upholds the prohibition of particular types of content of advertisement on the slender thread that the content may have some potential for misleading. See, e.g., id. at 9. This misuse leads to some startling conclusions. The court holds, e.g., that, since it might be misleading, the inclusion in an advertisement of an attorney's statement of his or her views on a matter of public interest is not protected by the First Amendment. Id. at 12. The court does not consider that such speech might have an even higher degree of protection than normal advertising content. See, e.g., New York Times Co. v. Sullivan, 376 U.S. 254 (1964), dealing with the constitutional protection of an advertisement that expressed opinions on issues of public interest and solicited money for a legal defense fund.

89. 609 S.W.2d at 412 . 
tude toward the state of the law in the wake of Central Hudson. Clearly, Central Hudson does provide an appropriate standard for judging any regulation of lawyers' promotional activities. It is true that Central Hudson, unlike In re R.M.J., did not deal with the advertisement of professional services. But the cases are similar in that they involve advertising by an enterprise that is highly regulated by the state. Central Hudson implicitly recognized this analogy by drawing on the professional services cases in establishing its standard. ${ }^{90}$ Moreover, Central Hudson can be viewed, not as a departure from the weighing approach articulated in Bates, but rather as an attempt to detail what such a weighing of interests entails. The following section demonstrates how Central Hudson can be applied to the various advertising and solicitation provisions of the state codes of professional responsibility. It also discusses the ensuing benefits of such an application, both for the public and for those lawyers wishing to communicate to potential clients.

\section{The Ethics Code Rules Governing the Promotion of Legal SERvices}

The ethics codes of all states and the District of Columbia include a version of Canon 2, the provisions of which govern the permissible content, format, and media of lawyers' promotional communications. The scope and nature of these rules vary widely from state to state. Some rules are designed to allow lawyers to tell potential clients about the nature, availability, and cost of their services, that is, to convey the information that the Bates Court noted the public needs. In contrast, other rules appear to be designed to cut the heart out of Bates and the other commercial speech cases by allowing lawyers to communicate only partial information and even that in ineffective ways.

\section{A. Restrictions on the Content of Lawyers' Communication to Potential Clients}

\section{General Provisions}

In recognition of the consumer's need for accurate information, each state, and the District of Columbia, has adopted rules against false, fraudulent, misleading, and deceptive communications. Such rules have precedent in the Federal Trade Commission actions requiring truthful nonmisleading product advertising. ${ }^{91}$ In addition, all the U.S. Supreme Court

90. Moreover, nothing in the professional service cases (Bates, Ohralik, Primus, and Friedman) suggests that the regulation of advertising of services is inherently sufficiently different from product advertising to require a different level of regulation.

91. Such actions are taken pursuant to the Frc's authorization under the Federal Trade Commission Act to regulate commercial activity to protect the consumer from unfair or deceptive acts or 
cases in this area have recognized that false, fraudulent, or misleading commercial speech can be prohibited.

\section{Regulation of Advertising Content}

Although all jurisdictions have provisions against false, fraudulent, misleading, and deceptive advertising, they vary in the other guidelines they apply to lawyers' advertisements. In Texas, after the Bates case was decided, the state supreme court ordered a suspension of those provisions of the Texas code of professional responsibility that conflicted with Bates. The order does not make clear exactly what type of communications will be permitted, although presumably the advertisement in print media of prices for routine services would be allowed, since such an advertisement was found to be constitutionally protected in Bates.

In contrast to the Texas Supreme Court's ambiguous order, the rules in the rest of the jurisdictions set explicit guidelines regulating lawyers' communications in the mass media..$^{92}$ Thirty-one states, basing their rules in part on the ABA Model Code of Professional Responsibility DR 2-101,93

practices. 15 U.S.C. $\S \S 41-58$ (1976 \& Supp. III 1979). See, e.g., Feil v. FTc, 285 F.2d 879 (9th Cir. 1960).

92. In addition, in some instances, the further regulations apply not just to mass media communications. In California, for example, the provisions in DR 2-101 govern all forms of dissemination of public communications-from speeches to advertisements.

93. The ABA Model Code of Professional Responsibility DR 2-101(B) provides that the attorney may advertise the following things:

(1) Name, including name of law firm and names of professional associates; addresses and telephone numbers;

(2) One or more fields of law in which the lawyer or law firm practices, a statement that practice is limited to one or more fields of law, or a statement that the lawyer or law firm specializes in a particular field of law practice, to the extent authorized under DR 2-105;

(3) Date and place of birth;

(4) Date and place of admission to the bar of state and federal courts;

(5) Schools attended, with dates of graduation, degrees and other scholastic distinctions;

(6) Public or quasi-public offices;

(7) Military service;

(8) Legal authorships;

(9) Legal teaching positions;

(10) Memberships, offices, and committee assignments, in bar associations;

(11) Membership and offices in legal fraternities and legal societies;

(12) Technical and professional licenses;

(13) Memberships in scientific, technical and professional associations and societies;

(14) Foreign language ability;

(15) Names and addresses of bank references;

(16) With their written consent, names of clients regularly represented;

(17) Prepaid or group legal services programs in which the lawyer participates;

(18) Whether credit cards or other credit arrangements are accepted;

(19) Office and telephone answering service hours;

(20) Fee for an initial consultation;

(21) Availability upon request of a written schedule of fees and/or an estimate of the fee to be charged for specific services;

(22) Contingent fee rates subject to DR 2-106(C), provided that the statement discloses whether percentages are computed before or after deduction of costs;

(23) Range of fees for services; provided that the statement discloses that the specific fee within the range which will be charged will vary depending upon the particular matter to be handled for each client and the client is entitled without obligation to an estimate of the fee within the range likely to be charged, in print size equivalent to the largest print used in setting forth the fee information;

(24) Hourly rate, provided that the statement discloses that the total fee charged will depend upon the num- 


\section{have adopted what is known as the regulatory approach to lawyer adver- tising. ${ }^{94}$ In these states, a lawyer may include in an advertisement only}

ber of hours which must be devoted to the particular matter to be handled for each client and the client is entitled to without obligation an estimate of the fee likely to be charged, in print size at least cquivalent to the largest print used in setting forth the fee information;

(25) Fixed fees for specific legal services, the description of which would not be misunderstood or be deceptive, provided that the statement discloses that the quoted fee will be available only to clients whose matters fall into the services described and that the client is entitled without obligation to a specific estimate of the fee likely to be charged in print size at least equivalent to the largest print used in setting forth the fee information.

American Bar Association, Model Code of Professional Responsibility and Code of Judicial Conduct (Chicago: American Bar Association, 1980).

Thirty-one states have a similar approach, regulating advertising content by listing the types of information that are appropriate to an advertisement. One of these states, Illinois, provides for a little leeway by including as one of its listed categories "other information about the lawyer, the lawyer's practice, or the types of legal matters in which the lawyer will accept employment, which a reasonable person might regard as relevant in determining whether to seek the lawyer's services." Ill. DR 2-101(a)(8).

The other 30 states with regulatory-style rules, however, do not allow the advertisement of any information beyond that listed. Of these states, 9 have adopted the ABA list of 25 permissible types of information with no more than minor changes in language: Alaska DR 2-101(B)(1)-(25); Ariz. DR 2-101(B)(1)-(25); Ark. DR 2-101(B)(1)-(25); Del. DR 2-101(B)(1)-(25); Neb. DR 2-101(B)(1)-(25); N.D. DR 2-101(B)(1)-(25); Wash. DR 2-101(B)(1)-(26); W. Va. DR 2-101(B)(1)-(25) (additionally, it gives examples of specific legal services); and Wyo. DR 2-101(B)(1)-(25). Fifteen states have adopted a modified version of the list: Colo. DR 2-101(B) (eliminates ABA DR 2-101(B)(6)-(11), (13), (15), (16), and modifies (21), (22), and (25)); Conn. DR 2-101(B)(eliminates ABA DR 2-101(B)(7), (11), (13), (15), (16), (24)); Ga. Std. 5(B) (eliminates ABA DR 2-101(B)(2), (6), (13), (16), (17), (22)-(24) and modifies (10) and (25)); Ind. DR 2-101(B) (eliminates ABA DR 2-101(B)(16)); Iowa DR 2-101(B) (modifies (1), (17), and provisions dealing with fee information); Kan. DR 2-101(B) (provides that the information described in (6), (11), and (16) shall not be published except in a reputable law list); Mont. DR 2-101(B) (eliminates ABA DR 2-101(B)(12)); Nev. Sup. Ct. Rule 164 (eliminates language in $A B A$ DR 2-101(B)(2) authorizing advertising of specialization, eliminates ABA DR 2-101(B)(3)-(13), (15)-(17)); N.M. DR 2-101(B) (does not allow information in ABA DR 2-101(B)(15) and (16) in print media other than law list or legal directories, allows the time alloted for an initial consultation to be advertised along with price); N.C. DR 2-101(B) (does not allow scholastic distinctions to be advertised in its equivalent of ABA DR 2-101(B)(5), eliminates ABA DR 2-101(B)(6), (7)-(13), (15), and (17), and adds examples of specific legal services in its equivalent to ABA DR 2-101(B)(25)); Ohio DR 2-101 (B) (can advertise age, but not date and place of birth as allowed under ABA DR 2-101(B)(3); information in ABA DR 2-101(B)(16) and (17) can be advertised only in law directories and law lists; eliminates ABA DR 2-101(B)(23)); S.C. DR 2-101(B) (eliminates ABA DR 2-101(B)(6), (7), (8), (11), (13) and modifies (23), (24) and (25) so as not to mandate size of print necessary for disclaimer); Tenn. DR 2-101(B) (modifies ABA DR 2-101(B)(1) to require that address and telephone number be by numerical designation only, to allow the information in (16) generally in approved law lists only, to expand (20) to allow for advertisement not only of a fee for an initial consultation but also of the absence of a fee and of the time limit, if any, on the consultation); Utah DR 2-101(B) (eliminates ABA DR 2-101(B)(23)); Vt. DR 2-101(D) (eliminates ABA DR 2-101(B)(13), (17), and (23), but expands to allow the advertisement of "posts of honor" and some fee information that the ABA rule doesn't). The remaining 6 states have created their own lists, with substantially fewer permissible items of information: Ala. DR 2-102(A); Ky. Rule 3.135; Miss. DR 2-102(A)(8); Mo. DR 2-101(B); Okla. DR 2-101(B); and R.I. Sup. Ct. Provisional Order No. 11, Oct. 30, 1979).

94. The committee that drafted ABA DR 2-101 described the regulatory approach as follows:

It would specifically authorize certain prescribed forms of lawyer advertising if approved by state authorities. It would seek in advance to channel commercial announcements but would rely on "after the fact" enforcement to discipline persons violating the regulation. It would follow the basic approach of several federal regulatory agencies, such as the Food \& Drug Administration and the Securities and Exchange Commission.

Task Force on Lawyer Advertising, ABA Board of Governors Report 177B, at 6 (1977), reprinted in Lori B. Andrews, Birth of a Salesman: Lawyer Advertising and Solicitation 91 (rev. ed. Chicago: American Bar Association, 1981). 
those items of information that are listed in the code provision. This is the type of rule at issue in In re R.M.J.

An alternative approach, taken by a substantial minority of states, is known as the directive approach to lawyer advertising. ${ }^{95}$ In the 19 jurisdictions that have adopted this approach, ${ }^{96}$ the advertising rules generally prohibit false, fraudulent, misleading, or deceptive (and sometimes selflaudatory or unfair) advertising.

These directive rules do not specify what a lawyer may advertise; they only provide the general guidelines for what a lawyer may not advertise. But even under these directive rules, a lawyer's freedom to communicate what is generally thought of as accurate and nonmisleading information is not unfettered. The directive rules usually provide definitions of what is considered false, fraudulent, misleading, or deceptive, which may include, for example, certain types of fee information ${ }^{97}$ or a statement that a lawyer is a justice of any court. ${ }^{98}$ Thus the "definitions" sometimes act to prohibit the disclosure of information that is not technically false or misleading but that the state wishes to deem to be false or misleading for other policy reasons.

In short, each state's code provisions, whether taking a regulatory or directive approach, contain some guidelines for advertising content beyond that it be accurate and nonmisleading. These guidelines cover the extent to which lawyers, in public communications, may identify legal problems, give biographical information, describe their firms, state the nature of their practices, give fee information, make reference to the quality of their services, or use emotional appeals.

In some cases, these guidelines prohibit lawyers from giving information that, according to surveys, the public needs. To a lesser extent, the content guidelines may prevent lawyers from using certain marketing techniques that have proven to be effective when used by other types of advertisers.

a) Content on Identification of Legal Problems $\square \square$ Before a person even decides to seek legal services, that person must be aware that he or she has a legal problem. There is evidence, however, that the public may not necessarily recognize that a certain action has legal ramifications or

95. The directive approach operates as follows: "It would allow publication of all information not 'false, fraudulent, misleading or deceptive,' and provides guidelines for the determination of improper advertisements, which would be subject to 'after the fact' discipline by state authorities." Id. at 7.

96. Cal. DR 2-101; D.C. DR 2-101; Fla. DR 2-101; Hawaii DR 2-101; Idaho DR 2-101; La. DR 2-101; Me. Rule 3.9; Md. DR 2-101; Mass. DR 2-101; Mich. Sup. Ct. Orders effective Mar. 15, 1978, and Feb. 2, 1979; Minn. DR 2-101; N.H. DR 2-101; N.J. DR 2-101; N.Y. DR 2-101; Or. DR 2-101; Pa. DR 2-101; S.D. DR 2-101; Va. DR 2-101; Wis. Sup. Ct. Order of April 30, 1979.

97. See, e.g., D.C. DR 2-101(B)(5).

98. See, e.g., N.H. DR 2-101(C)(11). 
realize that legal services could help solve a particular problem ${ }^{99}$ and that this failure to identify a problem as a legal one contributes to the infrequency with which people consult lawyers. ${ }^{100}$ Curran notes in the analysis of her national survey of the public's use of lawyers that "[1]awyers are consulted for slightly less than a third of all the problems encountered that reasonably could be called legal problems." 101

With the incentive of reaching an untapped market for legal services, lawyers may wish to include in advertisements an explanation of what a particular legal service entails and when it might benefit the consumer to obtain such a service. Based on survey results, this information would certainly be useful to people. However, such a communication would apparently not be permissible under the ABA model code or the rules in 30 states $^{102}$ that follow the regulatory approach to lawyers' ads. ${ }^{103} \mathrm{~A}$ lawyer might also wish to go beyond describing particular legal services and urge people to come in for a legal checkup to determine whether they had a legal problem. In a report to the ABA Commission on Advertising, the Connecticut Consulting Group found that the willingness to do preventive law was one of the six lawyer attributes that correlated most highly with favorable public attitudes toward lawyers ${ }^{104}$ and thus is apparently information that people might want in choosing an attorney.

Before the Bates case, it was apparently unethical for a lawyer to publicize the availability of a legal checkup ${ }^{105}$ unless such publicity was part of an organized bar association effort. Although in the states with directive-style rules ${ }^{106}$ advertisements for a legal checkup evidently are now

99. Commentary, Public and Professional Assessment of the Nebraska Bar, 55 Neb. L. Rev. 57 (1975) (examples of how lawyers and the public disagree on what constitutes a legal problem).

100. Missouri Bar, Missouri Prentice-Hall Survey: A Motivational Study of Public Attitudes and Law Office Management 36 (n.p.: Missouri Bar, 1963) (hereinafter, Missouri Survey). This theory is also set forth in Jerome E. Carlin \& Jan Howard, Legal Representation and Class Justice, 12 U.C.L.A.L. Rev. 381, 423-24 (1965), and Barbara A. Stein, Legal Services and the Middle Class, 53 N.D.L. Rev. 573, 580 (1977).

101. Curran, supra note 8, at 261.

102. See note 93 supra. However, such information apparently would be allowable in Illinois since it is arguably within the provision "other information about the lawyer, the lawyer's practice, or the types of legal matters in which the lawyer will accept employment, which a reasonable person might regard as relevant in determining whether to seek the lawyer's services." Ill. DR 2-101(a)(8). An advertisement explaining to the consumer how to identify legal problems would, however, be permissible under the rules in the 19 jurisdictions that have a directive rule generally allowing any information unless it is false, fraudulent, misleading, or deceptive. See note 96 supra.

103. Already, an informal disciplinary complaint has been filed against a group of lawyers who, in a state with regulatory style rules, included information in their advertisement to help women identify whether they had potential causes of action arising from the use of an allegedly defective intrauterine device known as the Dalkon Shield. The disciplinary authorities are charging the attorneys with violating the advertising rule by including information not specifically on the list.

104. Connecticut Consulting Group, ABA Commission on Advertising, Interim Presentation (manuscript, Mar. 1980).

105. ABA Formal Opinion 121 (Dec. 14, 1934); ABA Formal Opinion 307 (May 26, 1962).

106. See note 96 supra. 
permissible, such preventive law services apparently cannot be advertised in states with regulatory-style rules. ${ }^{107}$

The rules prohibiting information about the identification of legal problems or the availability of a legal checkup (in which the lawyer could identify problems) would not survive scrutiny under the Central Hudson test. Since commercial speech involving such information is not inherently false or misleading and does not concern unlawful activity, the analysis under Central Hudson would focus on whether there is a substantial government interest directly advanced in the least restrictive manner by a regulation prohibiting communication of the information.

One state interest that might be asserted is the prevention of the unauthorized practice of law. Officials might believe that providing the public with information about potential legal problems is analogous to encouraging the unauthorized practice of law. Some lay persons might feel that the information in an advertisement was sufficient to enable them to handle particular matters themselves-without consulting a lawyer.

However, this rationale is not a sufficient justification for prohibiting information from reaching people, because it overlooks two important factors. First, people have the right to represent themselves, and thus the concern about unauthorized practice is misplaced. Moreover, it is probably not likely that banning the use in ads of information about the identification of legal problems would encourage people to seek a lawyer when they needed one. If anything, the survey results (and common sense) imply the reverse is true-that people with legal problems who do not recognize them as legal problems will not seek an attorney at all.

A second potential government interest is the minimization of the amount of litigation. State officials might believe that providing people with information about identifying legal problems will encourage them to bring suits they otherwise wouldn't have, thereby increasing the perceived overabundance of litigation in our society. ${ }^{108}$ For example, it has been speculated that lawyers' advertisements explaining the new bankruptcy law led to an increased number of bankruptcy filings. ${ }^{109}$ Similarly, when the Missouri Bar sponsored advertisements advising people to "[s]ee a lawyer before, rather than after signing a contract," the Missouri Association of Realtors complained that the advertisements interfered with their closing of real estate transactions. ${ }^{110}$

107. See note 93 supra.

108. The public perception that we are swamped in lawsuits is discussed in two recent books, Marlene Adler Marks, The Suing of America: Why and How We Take Each Other to Court (New York: Seaview Books, 1981), and Jethro K. Lieberman, The Litigious Society (New York: Basic Books, 1981).

109. Helen Kaiser, Lawyer Ads: A Lure to Bankruptcy? Pitt. Press, Dec. 1, 1980, § B, at 1.

110. Andrews, supra note 94, at 79. 
Whatever the purported government interest in cutting down the amount of litigation, it does not justify a ban on information about the identification of legal problems. The possibility of litigation being stirred up was an issue raised early on by the State Bar of Arizona in Bates, but the Court did not consider this rationale compelling. "Although advertising might increase the use of the judicial machinery, we cannot accept the notion that it is always better for a person to suffer a wrong silently than to redress it by legal action." "n

A government interest deserving more serious attention, however, might be that of preventing the stirring up of baseless litigation. Justice Rehnquist, dissenting in In re Primus, argued against promotional activities by lawyers on the grounds that the powers of persuasion possessed by attorneys "may draw an unsophisticated layman into litigation contrary to his own best interests . . . and it may force other citizens . . . to defend against baseless litigation which would not otherwise have been brought." "112

But the Court in Bates had rejected the idea that curbs on lawyers' commercial speech could legitimately be used in an attempt to curb baseless litigation. The Court said that there is not an inevitable relationship between advertising and dishonesty ${ }^{113}$ and added: "Unethical lawyers and dishonest laymen are likely to meet even though restrictions on advertising exist. The appropriate response to fraud is a sanction addressed to that problem alone, not a sanction that unduly burdens a legitimate activity." 114 This is in keeping with the approach taken both in Virginia State Board of Pharmacy and in Bates, in finding that the protection of the performance standards in a profession was not sufficient justification for a ban on commercial speech. ${ }^{115}$

Thus, an advertising rule that prohibits lawyers from communicating information about the identification of legal problems (or about contacting a lawyer to learn more about identifying legal problems) is unconstitutional. It is not a content regulation that prohibits false, fraudulent, or misleading speech. Nor do the state interests involved rise to a level that supersedes the First Amendment free speech interest under a Central Hudson analysis. Even a substantial state interest, such as the prevention of baseless litigation, is insufficient to assure constitutionality, since the

111. 433 U.S. at 376 . Similarly, Morgan has pointed out, "If a person has a valid cause of action, surely there is neither a public interest nor a client interest in a conspiracy of silence among lawyers not to tell him about it." Thomas D. Morgan, The Evolving Concept of Professional Responsibility, 90 Harv. L. Rev. 702, 722 n.74 (1977).

112. 436 U.S. at 445 (Rehnquist, J., dissenting) (citations omitted).

113. 433 U.S. at 375 n.31.

114. Id.

115. Central Hudson, 477 U.S. at 564-65. 
regulation does not directly advance that interest. In addition, that same interest could be advanced by the less restrictive alternative of a regulation that prohibits baseless litigation.

b) Information about the Lawyer and the Lawyer's Firm $\square \square$ Another type of information that a potential client may wish to have and that a lawyer may wish to advertise concerns the lawyer's background. For example, a potential client may wish to know where an attorney went to law school and is admitted to practice and whether he or she has written law journal articles or served on bar committees in a certain substantive area or speaks a foreign language. Although under the directive approach, ${ }^{116}$ any true biographical information would generally be permissible as long as it was not misleading, those state rules following a regulatory approach $^{117}$ vary in the type of biographical information they allow. Rhode Island has the most restrictive rule on this point, providing that no biographical data nor the fact that an attorney serves as a part-time judge be advertised. ${ }^{118}$ Under the Missouri rule, lawyers may not advertise the names of the states in which they are licensed or the courts before which they are admitted to practice. ${ }^{119}$

In addition to information about a lawyer's background, a consumer may wish information about the lawyer's firm. ${ }^{120}$ The consumer may wish to know, for example, whether the law firm staff is sufficiently large and skilled to meet his or her needs, what other clients the firm serves, whether the office is in a convenient location, and what form of payment the firm accepts. When consumers learned about firms solely through word of mouth, this information could be elicited through conversation with the current and former clients of the firm. But now many potential clients must rely on other means of obtaining that information, such as through the mass media.

In states that follow the directive approach to regulating lawyer advertising, ${ }^{121}$ any true, nonmisleading information about an attorney's firm may be advertised. However, the regulatory-style ${ }^{122}$ rules allow the advertisement of only certain facts about a firm's location, references, and required manner of payment. These rules could prevent consumers from getting all the information they need about a firm. For example, under

116. See note 96 supra.

117. See note 93 supra.

118. R.I. Sup. Ct. Provisional Order No. 11(8).

119. Mo. DR 2-101(B).

120. The court in Durham v. Brock, 498 F. Supp. 213, 225 (M.D. Tenn. 1980), points out that because "large metropolitan firms tend to represent major corporations and wealthy individuals ... the firms which are perhaps best known are of the least usefulness to the individual legal consumer."

121. See note 96 supra.

122. See note 93 supra. 
the regulatory rules, a law firm apparently may not include in its advertisements the names and positions of paralegals, investigators, people admitted to the patent bar, or nonlawyer experts who are employees of the firm. ${ }^{123}$ In states with regulatory rules, the advertisement of even seemingly innocuous information may be grounds for discipline. Disciplinary action was brought against one Alabama law firm in part because its advertisement referred to "Free Parking" at the firm. ${ }^{124}$

Moreover, potential clients might wish to learn more than bare facts about a firm's location, references, and required manner of payment. Surveys indicate that people may be interested in the style of a firm's practice. They may want to know, for example, how much time they will be able to spend talking to a lawyer in an initial consultation or whether it will be easy to reach that lawyer in emergencies. A striking number of respondents in various surveys were dissatisfied with the general style of lawyers' practices. In Curran's national survey of lawyer usage and attitudes toward lawyers, 59 percent of the respondents believed that lawyers were generally not prompt, ${ }^{125}$ and 50 percent claimed that lawyers were not very good at keeping their clients informed of progress in their cases. ${ }^{126}$ In a Virginia survey, one-third of the respondents felt that lawyers were not good at explaining things in language the average person could understand. ${ }^{127}$

123. ABA Model Code DR 2-101(B)(1) allows the advertisement of the names of professional "associates," but the term associates has been interpreted as denoting a certain employer-employee relationship among lawyers. For that reason, an ABA ethics opinion stated that the term associates would be misleading if used where the lawyers involved share responsibility and liability (and thus are actually partners) or where two lawyers share a suite of offices and some costs but actually practice separately. ABA Formal Opinion 310 (June 20, 1963). According to a 1965 Oregon Supreme Court decision, "The word 'Associates' has a variety of meanings. Principally through custom the word when used on the letterheads of law firms has come to be regarded as describing those who are employees of the firm. Because the word has acquired this special significance in connection with the practice of the law the use of the word to describe lawyer relationships other than that of employeremployee is likely to be misleading." In re Sussman, 241 Or. 246, 248, 405 P.2d 355, 356 (1965). In states following the directive approach, primarily prohibiting information that is false, fraudulent, misleading, or deceptive, the inclusion of the names of nonlawyer associates in advertisements would appear to be permissible so long as there is no implication that they are lawyers or have a professional training beyond what they actually have. See note 96 supra.

124. Foley v. Alabama State Bar, 481 F. Supp. 1308, 1310 (N.D. Ala. 1979). The offer in an advertisement of free parking was said to violate the rule against giving a person valuable consideration in return for legal business.

125. Curran, supra note 8, at 229.

126. Id. at 230. See also Kent A. Wilson, Nebraskans, Lawyers, \& the Law: A Two-Year Analysis 32 (Oct. 9, 1980, manuscript-on file with the Nebraska State Bar Association) (32 percent of the respondents disagreed with the statement that lawyers were good at keeping clients informed).

127. Virginia Bar Association, A Survey of Adult Virginians Regarding Attitudes Toward Lawyers and the Legal Profession, table 10 (Sept. 1975), cited in Research Group, Inc., Questions Relating to Attorney Advertising: A Survey of Research and Experience, at I-27 (Virginia State Bar Committee on Lawyer Advertising, Oct. 20, 1978). But see Jack Kasulis \& Marie Adele Humphreys, Legal Services and the Oklahoma Public: A Survey, 50 Okla. B.J. 2491, 2493 (1979), which reports that only 11 percent of the respondents disagreed with the statement, "Lawyers generally explain in terms their clients understand what the client's legal problem is and how it can be solved." 
A lawyer who would like to communicate specific details about how his or her firm keeps clients informed or how the lawyers in the firm explain legal issues in an understandable way would not be able to do so under the 31 states that have regulatory-style rules. ${ }^{128}$ Yet information about how a lawyer practices and what a firm's philosophies are might be important to people who want to find a lawyer whose particular style matches their requirements. And from a marketing point of view, that sort of information would be one way the attorney could distinguish himself or herself from other lawyers who practice in the same substantive areas.

In judging the constitutionality of the state rules limiting the types of information lawyers can convey about themselves and their firms, it is necessary to examine the state interests presumably being advanced by such rules. In some states, such as Rhode Island, where lawyers may not include any biographical information in their promotional communications, there may be a governmental presumption that such information would be inherently misleading. For example, there may be a concern that consumers would be misled into thinking that a graduate of the Harvard Law School was more qualified than someone from a less prestigious law school (who in fact might be an equally or better qualified attorney). ${ }^{129}$

Under the ABA model code or state ethics codes that do allow the communication of at least some information about lawyers and their firms, advertising other information may be prohibited on the grounds that it should be irrelevant to the decision about hiring a lawyer. In fact, the Illinois ethics code sets as a standard for the type of information to be included in an advertisement that which is relevant in determining whether to seek the lawyers' services. ${ }^{130}$

Under a test of relevancy, an advertisement mentioning the color of an attorney's eyes might be deemed irrelevant. In other instances, certain information that a consumer might actually think relevant in selecting an attorney might be viewed by the state as irrelevant (e.g., that the firm offers free parking).

128. See note 93 supra.

129. The potential for misleading was discussed by a dissenting Missouri Supreme Court justice in In re R.M.J. with relation to the attorney's inclusion in his ad of the information that he was admitted to practice before the U.S. Supreme Court:

Although the fact of being admitted to the Supreme Court might impress a person looking for a lawyer, the question arises: does such information really help the consumer in obtaining needed legal services or is it more a device to seize his attention and to convey the idea that one who is admitted to the United States Supreme Court is per se a better lawyer? . . . I doubt that informational value gained by the consumer by advertising the isolated fact of admission to the United States Supreme Court justifies the risk of the false impression that such advertising may convey.

In re R.M.J., 609 S.W.2d 411, 416 (Mo. 1981).

130. Ill. DR 2-101(a)(8). 
These potential state interests in declaring information about a lawyer or his or her firm to be misleading or irrelevant boil down to a fear that people will choose lawyers for the wrong reasons and, presumably, suffer the consequences of having a lawyer who may be inappropriate for them. Yet the government does not require that people buying products choose their product for laudable reasons. When a consumer chooses a product because a celebrity uses it or it comes with a sweepstakes ticket, the government does not assert that there is a sufficient interest to intervene in some way. If anything, there should be less reason to interfere with consumers' choice of attorneys and other professional services providers than with a choice of products. The quality of professional services is itself regulated initially by the bar exam and then by the state ethics codes and thus, if a client does choose an attorney for the wrong reasons, there are independent reasons to suppose that the attorney will do an adequate job.

It is doubtful whether the need for protecting the public from choosing a lawyer for the wrong reasons is substantial enough to outweigh the First Amendment's protection of lawyers' commercial speech. Already, in Bates, the U.S. Supreme Court rejected the argument that a ban on advertising was justified because of the possibility that advertising would highlight irrelevant information and fail to show the relevant factor of skill.

[T] he argument assumes that the public is not sophisticated enough to realize the limitations of advertising, and that the public is better kept in ignorance than trusted with correct but incomplete information. We suspect the argument rests on an underestimation of the public. In any event, we view as dubious any justification that is based on the benefits of public ignorance. ${ }^{131}$

In addition, even if keeping irrelevant information from the public were a justifiable state interest, the rules of many of the states that take regulatory approaches to lawyer advertising would be unconstitutional under the Central Hudson test as not directly advancing the state interest involved or as not being the least restrictive approach since they prevent lawyers from advertising relevant as well as irrelevant information. A case in point is the Missouri rule ${ }^{132}$ at issue In re R.M.J., which prevents lawyers from referring in their advertisements to the states in which they are licensed to practice-information that would certainly be relevant to a consumer selecting a lawyer.

c) Information About the Nature of the Lawyer's Practice $\square \square$ In addition to information about a lawyer's background and the operation of

131. 433 U.S. at 374-75.

132. Mo. DR 2-101(B). 
his or her firm, consumers obviously need information about the type of law lawyers practice. In Bates, the Supreme Court observed that one reason people do not go to lawyers is that "they have no way of knowing which lawyers are competent to handle their particular problems." ${ }^{133}$ A person searching for a divorce lawyer, for example, may be at a loss when looking through the classified section of the telephone directory at a list of lawyers. How does the consumer find out which lawyers handle divorces?

The state rules do not allow lawyers to indicate in whatever manner they choose their willingness to provide services in a certain field. Instead, the state rules strictly delineate how a lawyer may communicate to the public the nature of his or her practice. At least one state has apparently decided that the inclusion of such information is inherently misleading. The Oklahoma rule prohibits lawyers from advertising the field of law their practices cover. ${ }^{134}$

Routine services. Some restrictions on how lawyers may describe their areas of practice to potential clients make up part of the advertising rules in the state versions of ABA model code DR 2-101 and 2-102. Six states control how lawyers describe their areas of practice by allowing attorneys to advertise the prices of only certain enumerated routine legal services. ${ }^{135}$

133. 433 U.S. at 370-71 n.23 (citing ABA, Legal Services \& the Public, 3 Alternatives 15 (Jan. 1976)).

134. Okla. DR 2-101(B)(8).

135. The following states allow price advertisements only for the enumerated routine services. Del. DR 2-101(C)(1)-(9) (uncontested divorces; uncontested adoptions; uncontested personal bankruptcies; changes of name; deeds, bonds, mortgages, and certain security agreements; promissory notes; powers of attorney; bills of sale; and uncomplicated wills); Ga. Std. 5(B)(14)(a)-(e) (certain uncontested adoptions; uncontested name changes; certain uncontested divorces; certain voluntary no-asset bankruptcies; debt collection); Iowa DR 2-101(D)(1)-(12) (abstract examinations and title opinions not including services in clearing title; uncontested dissolutions of marriage involving no disagreement concerning custody of children, alimony, child support, or property settlement; wills leaving all property outright to one beneficiary or one class of beneficiaries; income tax returns for wage earners; uncontested personal bankruptcies; changes of name; simple residential deeds; residential purchase and sale agreements; residential leases; residential mortgages and notes; powers of attorney; bills of sale; Miss. DR 2-102(A)(8) (uncontested divorces; uncontested adoptions; uncontested personal bankruptcies; changes of name; deeds, promissory notes, security agreements; and deeds of trust; powers of attorney; individual income tax returns; bills of sale; wills; and initial conference with clients); Mo. DR 2-101(B)(10) (uncontested dissolutions of marriage; uncontested adoptions; uncontested personal bankruptcies; uncomplicated changes of name; simple warrant or quitclaim deeds; simple deeds of trust; simple promissory notes; individual Missouri or federal income tax returns; simple powers of attorney; and simple wills); R.I. Sup. Ct. Provisional Order No. 11(3) (uncontested divorces, simple adoptions, uncontested personal bankruptcies, changes of name, simple residential deeds, residential purchase and sale agreements, residential leases, residential mortgages and notes, powers of attorney, individual income tax returns, simple wills, bills of sale, collections, and charge for an initial conference with a client).

As can be seen, some states have taken such a restrictive approach to the type of routine services a lawyer may advertise that they do not even allow advertisement of some of the services mentioned in the Bates ad. The advertisement at issue in the Bates case mentioned, and quoted prices for, the following services: uncontested divorces and legal separations, adoption proceedings, individual and joint uncontested bankruptcy proceedings," and name changes. 433 U.S. at 385 app. Yet Iowa, e.g., does not allow the mention of uncontested adoption in lawyer advertisements. In addition, in some 
These states have apparently interpreted Bates narrowly to justify limiting price advertisement to routine matters. It is obvious, however, that the fact that the advertisement in Bates dealt only with routine services does not require the line of constitutionality to be drawn at that point. The Bates Court most likely did not intend to say that it is constitutional to forbid the advertising of nonroutine services but rather assumed as a practical matter that most lawyers' advertisements would deal only with routine services. ${ }^{136}$ Indeed, limiting price advertisements to routine services would probably be unconstitutional under Central Hudson. If the government's concern is that a lawyer might advertise complicated services at unrealistically low prices and then charge the client a higher-thanadvertised fee, that possibility is already prohibited by the disciplinary rules against misleading advertising and fraudulent conduct. ${ }^{137}$ If the government's goal is to prevent lawyers from misleading the public into thinking they have expertise they do not in fact have, a more direct and less restrictive approach would be to let attorneys describe their practices as they wished but require such communications to contain appropriate disclaimers (e.g., that the attorney was not a certified specialist in the area described). ${ }^{138}$

Specialized services. In addition to those advertising rule restrictions regarding routine services, the specialization rules in the state versions of ABA model code DR 2-105 cover how lawyers may communicate information on the nature of their practices to potential clients. In many states the two provisions are interrelated, following ABA model rule DR $2-101(B)(2)$, which allows advertising of the nature of a lawyer's practice only to the extent that this communication complies with the specialization rule, DR 2-105.

The latter rule operates as follows. The introductory provision of ABA DR 2-105 prohibits lawyers from holding themselves out either as specialists, as practicing in certain areas of law, or as limiting their practice. In

states matters are considered routine that are not so considered in other states. In Georgia, the preparation of a "simple will" is apparently not so simple since it is not included among the routine legal services of which advertising is permitted.

136. The Court noted: "Economic considerations suggest that advertising is a more significant force in the marketing of inexpensive and frequently used goods and services with mass markets, than in the marketing of unique products or services." 433 U.S. at 372 n.25.

137. See text and note at 177 infra.

138. A model for the disclaimer is already provided by $\mathrm{Pa}$. DR 2-105(B) and Tenn. DR 2-101(B) (2), which require that lawyers who publicly communicate that they limit their practice include a disclaimer stating that the lawyer is not certified or recognized as a specialist. The Tennessee rule even provides the language for the statement: "[I] [We] [This law firm] [The legal clinic] neither assert[s,] [imply] [implies] or [claim[s]] any particular knowledge or expertise above that of other lawyers in this community." Ohio also requires a disclaimer, but allows only a more limited communication of the nature of a lawyer's practice. In Ohio, if a lawyer advertises other than routine services, he or she must include in the advertisement a statement that he or she is not designated or certified as a specialist. Ohio DR 2-101(B)(2)(b). 
three exceptional instances, however, lawyers may communicate the nature of their practice. They may state that they practice patent law (if they are admitted to practice before the U.S. Patent and Trademark Office), they may describe their practice according to designations authorized by a state agency, and they may hold themselves out as a specialist if they have complied with a state specialization program. Virtually all the state codes include similar provisions, although some modify the general rule to cover more activities. For example, the general provisions in the state ethics codes variously cover holding oneself out as a specialist; ${ }^{139}$ holding oneself out as a recognized, designated, or certified specialist; ${ }^{140}$ implying specialization; ${ }^{141}$ holding oneself out as limiting one's practice to, ${ }^{142}$ concentrating in, ${ }^{143}$ practicing in, ${ }^{144}$ or emphasizing certain areas of practice. ${ }^{145}$ In addition to varying the scope of the general provision from that of the ABA model, many state ethics rules expand or contract the available exceptions while still retaining the general ABA rule format. ${ }^{146}$ Finally, a small minority of states have totally different approaches to the issue of communicating the nature of one's practice. ${ }^{147}$

At issue in In re R.M.J. is that portion of the Missouri specialization rule that requires lawyers to describe their practice according to certain officially sanctioned designations. This provision, based on ABA Model Code of Professional Responsibility DR 2-105(A)(2), is followed in 16 states. ${ }^{148}$ In Missouri, an attorney may describe the nature of his or her practice according to the broad categories of "General Civil Practice," "General Criminal Practice," or "General Civil and Criminal Practice," or the lawyer may use one or more items from a list of 23 specific categories. ${ }^{149}$

The Missouri attorney whose communications are at issue in In re $R . M . J$. included 23 areas of law in a Yellow Pages advertisement. Only 4 of these areas were described in the exact language the Missouri rule required. ${ }^{150}$ Eight other areas that the attorney listed-contract, aviation, securities and bonds, pension and profit-sharing plans, zoning and land use, entertainment/sports, communications, and food, drug, and cosmet-

139. See, e.g., Mo. DR 2-105(A).

140. See, e.g., Me. Rule 3.8.

141. See, e.g., Or. DR 2-105.

142. See, e.g., Mo. DR 2-105(A).

143. See, e.g., Or. DR 2-105.

144. See, e.g., Mo. DR 2-105(A).

145. See, e.g., Del. DR 2-105(A).

146. See, e.g., Alaska DR 2-105(A) and Ariz. DR 2-105(A).

147. See, e.g., Me. Rule 3.8 and S.D. DR 2-105(A).

148. Alaska DR 2-105(A)(2); Ariz. DR 2-105(A)(2); Conn. DR 2-105(A)(5); Fla. DR 2-105(1); Iowa DR 2-105(A)(2) and (3); Mo. Addendum to DR 2-101(B)(2); Mont. DR 2-105(A)(2); Nev. DR 2-105(A)(2); N.M. Rule 2-105(C); N.C. DR 2-105(B); N.D. DR 2-105(A)(2); Okla. DR 2-105(A)(4);

S.C. DR 2-105(A)(2); Utah DR 2-105(B); W.Va. DR 2-105(A)(2); and Wyo. DR 2-105(A)(2).

149. Mo. Bar Advisory Committee Addendum to Mo. DR 2-101(B)(2).

150. Bankruptcy, antitrust, labor, and criminal. 
ic-were not included on the Missouri list at all. The other areas he listed were impermissible since they were variations on the approved designations. For example, he listed "Personal Injury Law," while the approved designation was "Tort Law." He listed "Real Estate" instead of "Property Law," "Workmen's Compensation" instead of "Workers Compensation," and "Divorce," "Separation," "Custody," and "Adoption" instead of "Family Law." He also listed "Trials \& Appeals" instead of "Trial Practice" and "Appellate Practice," and "Corporate" and "Partnership" rather than "Corporation Law and Business." Presumably, the attorney in this case did not use officially sanctioned designations in some instances because he believed a variation on those designations would be more readily recognized by the public. ${ }^{151}$

Since the specialization rules govern the content of a lawyer's advertisements, they deserve close analysis under Central Hudson. The requirement that lawyers not hold themselves out as specialists unless they have complied with a specialization program would probably be found constitutional because it is merely a specific application of the provision that communications not be false, fraudulent, or misleading. ${ }^{152}$ It is questionable, however, whether the designation list could pass constitutional muster.

The ostensible state interest in requiring a list of this sort is to establish a set of commonly used terms to aid the public in understanding what certain areas of practice entail and in making comparisons among lawyers in a given practice area. But at present this list approach has a number of drawbacks. In some states where descriptions of practice must conform to officially sanctioned designations, no such lists have yet been promulgated, ${ }^{153}$ so attorneys are effectively prevented from advertising their areas of practice at all. In states that have promulgated lists, the designations might be incomprehensible to the lay public, and certain important areas of law may be left out. For example, in Utah ${ }^{154}$ the permissible terms "Appellate Practice" or "Product Liability" might not be immediately recognized by the public. And a person with a job discrimination

151. In his brief, R.M.J. says that he used the term "Personal Injury," rather than the thenapproved term "Tort Law" because it is "accurate, descriptive, and generally understood." In addition, he argues that the currently approved term "Negligence Law" "in this era of strict liability, does not accurately describe the range of actions for personal injury." Appellant's Brief, In re R.M.J., No. 80-1413, at 27 (U.S. Sup. Ct. 1980).

152. This is based on the assumption, of course, that people who hear the word specialist used with respect to lawyers understand it to mean certified by some official body in a particular field. Since this is the meaning the term generally has in the medical field, where consumers have heard it for years, this is an understandable assumption. So even in states without programs, lawyers can probably constitutionally be prohibited from saying they are specialists or recognized specialists.

153. Apparently, for example, Nevada, West Virginia, and Wyoming have not yet adopted designation lists.

154. Utah DR 2-105(B). 
case might not know whether the category "Labor Law" would cover his or her legal problem. Thus, it is questionable whether the regulation directly advances a substantial governmental interest, since the rule itself may contravene the purpose of presenting understandable information. In addition, it is clearly not the least restrictive approach. If the objective is to assure that the public understands what the lawyer's practice entails, lawyers should be given the option of including explanatory information in their advertisements rather than being forced to use what may be an inappropriate and possibly incomprehensible term.

Much of the bar's concern with regulating whether and how a lawyer may describe his or her practice seems based on the concern that a listing of an area of practice implies specialization in that area and thus is misleading to the public. Clearly, however, a rule requiring that lawyers describe their practices according to officially sanctioned designations does not meet that concern (e.g., in Missouri the permissible term, "Negligence Law" does not convey any less of a sense of expertise than does the impermissible "Personal Injury Law").

Moreover, as one commentator has pointed out, the concern about deception may be overemphasized since lawyers who communicate their availability to accept cases in a certain area of law will probably be more likely to provide quality services in that area than randomly chosen lawyers. ${ }^{155} \mathrm{He}$ also notes:

Lawyer referral services have, for a number of years, been assigning clients to particular lawyers based solely on the lawyers' assertions as to which cases they believe themselves competent to handle. If the system of self-certification of specialty were so unworkable, it seems inconceivable that the Bar would have selected it for its own referral process. ${ }^{136}$

Whatever the potential for deception, there are less restrictive alternatives than a total ban on nature-of-practice information or a limitation of such information to a state-sanctioned list. Examples of such alternatives would be the use of a disclaimer of the sort suggested earlier regarding routine legal services ${ }^{157}$ or a provision modeled after the rules now in use

155. Morgan, supra note 111 , at 718.

156. Id.

157. Such a disclaimer has already been dealt with at the federal district court level. In Durham v. Brock, 498 F. Supp. 213 (M.D. Tenn. 1980), the court held that prohibiting an attorney from listing routine legal services without prices or listing his areas of practice was unconstitutional. The court noted that listing one's area of practice or the availability of routine legal services "is information which is valuable to the consumer. It is a practical reality of the legal profession that not all lawyers practice all law." Id. at 225. The purported state interest involved was the prevention of deceptiveness since "[s]uch statements are calculated to convey to the lay public the impression that the lawyer is a specialist and, therefore possesses particular expertise in the advertised field." Id. at 223, quoting In re Petition for Rule of Court Governing Lawyer Advertising, 564 S.W.2d 638, 645 (Tenn. 1978). However, the court held that the Tennessee rule prohibiting all nature of practice information except that of routine legal services with prices was not the least restrictive approach. The court held: 
in a minority of states. ${ }^{158}$ These rules allow publicizing information regarding the nature of lawyers' practices but specify that it may not be false, fraudulent, or misleading, and specifically state that lawyers may not hold themselves out as recognized specialists unless they are in fact certified by the state.

d) Cost of Services $\square \square$ The Bates Court pointed out that "[s]tudies reveal that many persons do not obtain counsel even when they perceive a need because of the feared price of services." ${ }^{159}$ Curran's national survey on the legal needs of the public found a great concern among respondents about the cost of legal services. In the survey, 68 percent of the respondents felt lawyers charged more than they were worth, ${ }^{160}$ and 51 percent felt lawyers' fees were not usually fair to clients, regardless of how the fee was figured. ${ }^{161}$ Similar concerns about cost were echoed by respondents in

\begin{abstract}
"There are many ways in which deception in a facially truthful advertisement may be cured short of total prohibition. . . . Certainly a lawyer's advertisement which stated that his practice was limited to domestic relations but which was accompanied by a warning or disclaimer that no particular expertise above that of the general legal community was asserted or implied would not mislead a consumer as to the quality of the legal services being offered." Id. at 225. (It is interesting to note that although this Tennessee case was decided before Central Hudson, it, too, advocated a least-restrictive-alternative approach. It did so on the basis of language in Virginia Pharmacy, including the language that the First Amendment makes the choice between the dangers of suppressing information and the dangers of its misuse. Id. at 224 n.20.)

However, the court in Lovett \& Linder, Ltd. v. Carter, C.A. No. 81-0118 (D.R.I., Sept. 8, 1981), upheld limitations on nature of practice information and rejected the possibility of a disclaimer. The court pointed out that a listing of area of practice is misleading: " $A$ lay reader and even experts in other professions are expected to conclude that the attorney is especially qualified in the areas of law mentioned." Slip op. at 24-25. In the ad at issue in the Rhode Island case, the law firm had listed its areas of practice and stated, "We make no claim of expertise or specialization in these matters." Id. at 4. Although such a disclaimer would appear to allay the potential for deception, the court found the ad with the disclaimer to be "even more pernicious" than an ad without one because "it deliberately states an untruth, i.e., lack of expertise in areas in which the lawyer believes that he or she is a qualified expert." Id. at 25 .

In a very tenuous bit of reasoning, the court implies that the appearance of an attorney in court arguing, e.g., a personal injury case is a claim of expertise in that field and, thus a disclaimer, "We make no claim on expertise or specialization in these matters," is untrue. Id. at 10. However, the court's logic is confounded at best. Since all lawyers are licensed to practice in all areas of law, the appearance of an attorney in court on a given matter in no way indicates that the attorney is holding himself or herself out as a specialist in the type of case at issue. Moreover, the court overlooks the differences between considering oneself an expert, being an expert, and holding oneself out as an expert. Even an expert (or one who considered oneself an expert) in an area of law could truthfully state in an advertisement that he or she was making no claim of expertise.
\end{abstract}

158. See, e.g., Hawaii DR 2-105; D.C. DR 2-105(B); Mass. DR 2-105(B); N.J. DR 2-105(A)(2); Va. DR 2-104(B). The Delaware rule goes one step further by explaining what type of nature of practice information would be considered truthful. Although under the Delaware rule lawyers may list the areas they practice in or engage in without further restrictions, if they say that they limit their practices to certain areas, they must spend 25 percent or more of their time in that area and must follow certain procedures to let the grievance committee know they are in compliance with that rule. Del. DR 2-105(A)(2). In addition, their public communications about the limitation of their practices must state that they are not certified or recognized as specialists in the areas of practice listed. Id.

159. 433 U.S. at 370.

160. Curran, supra note 8, at 231.

161. Id. 
more recent surveys in Illinois, Nebraska, and North Dakota. ${ }^{162}$ In a study in Oklahoma, although 86 percent of respondents thought costs deterred people from using lawyers' services, 70 percent agreed with the statement, "On average, I would be willing to pay a lawyer $\$ 25$ for a 30 -minute consultation." 163 As the researchers who conducted the study point out, "Since $\$ 25$ for a 30-minute initial consultation is not an unusually low fee, it appears that the perception of high fees may be based on a lack of accurate information among the public about legal fees and the services offered by lawyers." 164

Allowing lawyers to communicate to the public the cost of their services would apparently benefit both potential clients and lawyers. Clients would be able to tell whether they could afford to consult a particular lawyer and the lawyer promoting his or her services would be able to attract clients who would otherwise be deterred from seeking such services because of misperceptions about the cost of those services. However, it is not always possible to advertise price information under the state codes.

Under some regulatory-style rules, certain types of fees are not included in the list of permissible information to be advertised. For example, the rule in Connecticut does not allow the advertisement of an hourly rate, ${ }^{165}$ and the rules in Ohio, Utah, and Vermont do not allow the advertisement of a range of fees for services. ${ }^{166}$ Eight states do not permit the advertisement of a contingency fee. ${ }^{167}$

A recent analysis based on the national survey on the legal needs of the public determined that closed-panel prepaid plans, along with legal clinics, were the service delivery mechanisms that "offer the greatest promise for fulfilling the large, unmet public legal need that has long troubled the organized bar." 168 However, in a number of states, lawyers are not permitted to advertise that they participate in a prepaid plan. ${ }^{169}$

Some state rules also govern how lawyers may characterize their fees. The ad at issue in the Bates case offered routine legal services at "very

162. James E. Haefner, Advertising Effectiveness Study Prepared for the Illinois Bar Association (April 4, 1977); Wilson, supra note 136, at 31, 35 (82 percent of respondents felt most lawyers charge more for their services than the services are worth); John Thomason, What the Public Thinks of Lawyers, 46 N.Y. St. B.J. 151, 154, (1974) (nearly half the North Dakota respondents who had not consulted a lawyer said uncertainty about cost was a primary reason).

163. Kasulis \& Humphreys, supra note 127, at 2492.

164. Id.

165. Conn. DR 2-101(B).

166. Ohio DR 2-101(B), Utah DR 2-101(B), and Vt. DR 2-101(D).

167. Information about contingency fees is not included in the lists of permissible information in Ala. DR 2-102(A)(7)(b); Colo. DR 2-101(B); Ga. Std. 5(B); Ky. Rule 3.135; Miss. DR 2-102(A)(8); Mo. DR 2-101(B); Okla. DR 2-101(B); and R.I. Sup. Ct. Provisional Order No. 11(3).

168. Project, supra note 9, at 155.

169. E.g., some states that have based their lawyer advertising rules in general on the ABA model have stricken the provision (ABA Model Code DR 2-101(B)(17)) that allows the communication of information about the lawyer's" participation in a prepaid plan. See, e.g., Ga. Std. 5(B); Nev. Sup. Ct. R. 164(2); N.C. DR 2-101(B); Vt. DR 2-101(D). 
reasonable fees." ${ }^{170}$ Vermont is the only state that includes a provision specifically allowing in advertisements a "statement of the reasonableness or fairness of fees either in general or in relation to fees charged by the majority of lawyers in the community or in relation to past or future fees charged by the lawyer, if not clearly inaccurate." ${ }^{171}$ Two states specifically prohibit references to the reasonableness of fees. ${ }^{172}$ Another state provides that "[s]pecial rates may not be advertised nor is the use of "loss leader' type advertising permissible." ${ }^{173}$ A recent federal district court case held unconstitutional a prohibition on characterizing fees as reasonable but upheld the prohibition against various other fee characterizations. ${ }^{174}$

Even some of the directive-style rules have limitations on the types of fee information that may be advertised. Although the directive rules allow the advertisement of any true information about lawyers' backgrounds, their firms, or the nature of their practices so long as that information is not misleading, some states with directive rules specifically list the type of fee information that is permissible. ${ }^{175}$ Advertisement of fee information that is not on the permitted list is considered to be misleading.

Some of the regulations governing price advertising are clearly against the public interest and in violation of lawyers' freedom of speech. It would seem that prohibiting lawyers from advertising hourly rates is designed less to protect the public than to protect nonadvertising lawyers from competition. This state interest is not sufficient to justify such a regulation under Central Hudson.

The type of price advertising regulation that is most clearly justifiable on public protection grounds is that preventing bait and switch. Rhode Island attempts this sort of rule by providing that if a deviation from the fixed fee advertised could occur, the advertisement must contain a disclaimer indicating that in some circumstances a fee may exceed the adver-

170. 433 U.S. at 385.

171. Vt. DR 2-101(D)(5).

172. Under La. DR 2-101(F), advertising or other publicity by lawyers may not make any comment as to the reasonableness of the fees for services proposed. Mississippi State Bar Ethics Opinion No. 44 (Sept. 16, 1977) also provides that no reference may be made to the reasonableness of the fee to be charged.

173. Tenn. DR 2-102(E).

174. Iowa DR 2-101(A) had provided that a lawyer must "avoid all subjective characterizations of his rates or fees, such as, but not limited to, 'cut rate', 'lowest', 'reasonable', 'moderate', 'very reasonable', 'give away', 'below cost', [and] 'special'." However, in an attorney's recent challenge of the Iowa rule, in Bishop v. Committee on Professional Ethics \& Conduct, Civ. No. 81-47-D. (S.D. Iowa, Aug. 20, 1981), the court held that "DR 2-101(A), insofar as it prohibits plaintiff's verifiable truthful use of restrained adjectives characterizing his fees . . . violates his First Amendment right of commercial speech." Id. at 10. The court did hold that certain adjectives such as "cut-rate," "lowest," "give-away," "below cost" and "special" could be prohibited due to their high potential to mislead. Id.

175. See, e.g., D.C. DR 2-101(B)(5); Fla. DR 2-101(B)(6); Hawaii DR 2-101(B)(6); Idaho DR 2-101(B)(6); La. DR 2-101(F); N.H. DR 2-101(D); N.J. DR 2-101(B)(5); S.D. DR 2-101(B)(6). 
tised amount. ${ }^{176}$ But a specific rule on bait and switch may be unnecessary; it would appear to be covered by the provision prohibiting misleading advertising. ${ }^{177}$ In any case, a rule preventing lawyers from advertising certain types of fee information-without at least allowing such information with a Rhode Island-type disclaimer-would be unconstitutional under the Central Hudson test since it is too broad to serve the government interest at stake.

e) Quality Representations $\square \square$ A number of states have adopted rules that specifically indicate whether or under what circumstances a lawyer may make statements in advertisements regarding the quality of services. Most states prohibit lawyers from using self-laudatory statements ${ }^{178}$ in advertisements and some states prohibit puffery; ${ }^{179}$ both provisions might be interpreted as prohibiting lawyers from referring in advertisements to the quality of their services.

In states with regulatory rules, ${ }^{180}$ statements about quality would apparently not be allowed since they are not included in the enumerations of permissible information. In Alabama, moreover, all advertising by lawyers must contain the statement, "No representation is made about the quality of services to be performed or the expertise of the lawyer performing such services." 181

176. R.I. Sup. Ct. Provisional Order No. 11(3).

177. In addition, other provisions of the code protect against misleading conduct on the part of attorneys, and thus would cover misleading advertising. For example, ABA Model Code DR 1-102(A) (4) provides that attorneys shall not "[e]ngage in conduct involving dishonesty, fraud, deceit or misrepresentation." Hellman, supra note 87 , at 538, argues that an advertising rule against bait-andswitch tactics is unnecessary, since such actions are already prohibited whether or not they are done by an advertising lawyer. "Whenever a person walks in off the street and requests a routine legal service, such as a standard will, the lawyer is in a position to disparage the less expensive service and switch the client to a more expensive transaction than the client's needs require. . . . Surely the [court] does not view such behavior as unpunishable under the Code because it does not involve advertising."

178. Ala. DR 2-101(A); Alaska DR 2-101(A); Ariz. DR 2-101(A); Ark. DR 2-101(A); Colo. DR 2-101(A); Conn. DR 2-101(A); Del. DR 2-101(A); D.C. DR 2-101(C)(4); Fla. DR 2-101(C)(6); Ga. Std. 5(A) (a lawyer may not use a self-laudatory statement to attract lay clients); Idaho DR 2-101(C) (6); Ind. DR 2-101(A); Iowa DR 2-101(A); Kan. DR 2-101(A); Ky. Rule 3.135; La. DR 2-101(C); Mo. DR 2-101(A); Mont. DR 2-101(A); Neb. DR 2-101(A); Nev. Sup. Ct. Rule 164(1); N.J. DR 2101(C)(4); N.M. DR 2-101(A); N.Y. DR 2-101(B); N.C. DR 2-101(A); N.D. DR 2-101(A); Ohio DR 2-101(A); Okla. DR 2-101(A); S.C. DR 2-101(A); S.D. DR 2-101(C)(6); Tenn. DR 2-101(A); Utah DR 2-101(A); Vt. DR 2-101(A); Wash. DR 2-101(A); W.Va. DR 2-101(A); and Wyo. DR 2-101(A).

179. Fla. DR 2-101(C)(6); Ga. Std. 5(C)(2); (no puffery in broadcast commercials); Idaho DR 2-101(C)(6); La. DR 2-101(C); N.H. DR 2-101(C)(10); N.M. DR 2-101(D)(2); N.Y. DR 2-101(B); S.C. DR 2-101(A)(2)(F); and S.D. DR 2-101(C)(6).

180. Note 93 supra. In addition, some regulatory rules specifically state that a lawyer may not make quality representations. Ala. DR 2-102(A)(7)(C); Iowa DR 2-101(A); N.M. DR 2-101(A); and R.I. Sup. Ct. Provisional Order No. 11(4). The Iowa rule prohibiting statements as to quality was upheld in Bishop v. Committee on Professional Ethics \& Conduct, Civ. No. 81-47-D (S.D. Iowa, Aug. 20, 1981). Although the South Carolina rule is a regulatory-style rule, and quality representations do not appear as a permissible item on the list, S.C. DR 2-101(A((2)(d) states that a lawyer may not make a representation or implication as to quality "which is not susceptible of reasonable verification by the public."

181. Ala. DR 2-102(A)(7)(f). 
Other specific types of statements that might imply quality are prohibited, even in some states with directive-style rules. These include prohibitions on the use of statistical data or other information regarding past performance or future success, ${ }^{182}$ testimonials or endorsements, ${ }^{183}$ or any comparative statement regarding any other lawyer. ${ }^{184}$ Moreover, four states with directive-style rules prohibit representations about quality altogether. ${ }^{185}$

Yet members of the public are interested in receiving accurate information about the quality of lawyers' services. ${ }^{186}$ In other areas, the Federal Trade Commission has encouraged the use of comparative advertising and other indications of quality as helpful to consumer decision making. State rules preventing lawyers from making quality statements thus seem to demonstrate a greater concern for protecting lawyers than for protecting the public.

The prohibition against various types of claims of quality appear to prevent a lawyer from communicating the sort of information that sets him or her apart as being particularly competent. For example, such a rule seems to prohibit a lawyer from communicating that he graduated first in his class at Harvard Law School or published numerous articles on a particular topic. However, this might be just the sort of information that a consumer might want to consider in selecting a lawyer. Although it could be argued that a prohibition against quality claims is necessary to protect the public from "puffing," it may well be that consumers are already so used to discounting the "puffing" in communications about products that they will likewise be able to give self-laudatory comments in lawyers' communications their proper weight. The rationale for the prohibition of self-laudatory statements is their potential for misleading, but a statement that is false or self-laudatory in a misleading way

182. D.C. DR 2-101(C)(1); Fla. DR 2-101(C)(2); Hawaii DR 2-101(C)(2); Idaho DR 2-101(C)(2); La. DR 2-101(C)(1) and (2); N.H. DR 2-101(C)(6); N.J. DR 2-101(C)(1); N.M. DR 2-101(A); Or. DR 2-101(A)(3)(a); and S.C. DR 2-101(A)(2)(b). Similarly, a California board of governors resolution dated June 19, 1979 (incorporated into the disciplinary rules as a result of Cal. DR 2-101(D)), prohibits communications which contain guarantees, warranties, or predictions regarding the result of legal action.

183. Cal. DR 2-101(D), incorporating a board of governors resolution dated June 19, 1979, Std. 2; D.C. DR 2-101(C)(2); Fla. DR 2-101(C)(3); Idaho DR 2-101(C)(3); La. DR 2-101(C)(3); N.H. DR 2-101(C)(7); N.J. DR 2-101(C)(2); N.M. DR 2-101(A); Or. DR 2-101(A)(3)(b); S.C. DR 2-101(A)(2) (c); and S.D. DR 2-101(C)(3).

184. La. DR 2-101(C)(5) and N.M. DR 2-101(A).

185. Idaho DR 2-101(C)(4); La. DR 2-101(C); N.Y. DR 2-101(B); and Or. DR 2-101(A)(3)(b).

186. The need for information about the quality of a lawyer's services is indicated by the fact that 83 percent of the people contacted in the Curran survey agreed with the statement that people do not go to lawyers because they have no way of knowing which lawyers are competent to handle their particular problem. Supra note 8. A substantial minority in the Curran survey expressed outright concern with the quality of lawyers' services. Thirty-nine percent of respondents felt that lawyers would take a case even if they did not feel sure they knew enough about that area of law to handle the case well. Id. at 229. 
will already be prohibited by those provisions requiring communication to be accurate and nonmisleading. For example, the self-laudatory statement "I have never lost a job discrimination case" made by a lawyer who had never taken a job discrimination case, although apparently true on its face, would be prohibited as misleading.

The Bates Court seemed to find quality claims problematic, stating in dicta that quality claims "are not susceptible of measurement or verification; accordingly, such claims may be so likely to be misleading as to warrant restriction." ${ }^{\prime 87}$ But clearly some claims that involve implications of quality could be verified. Moreover, the terms "self-laudatory," "puffery," and "representations about quality" are so broad and ambiguous that there is the potential for this very general prohibition to be used to prohibit accurate statements, for example, that the lawyer is a former U.S. solicitor general or that he or she served as the chairperson of a particular bar association committee. If the state's goal is to protect the public from being misled, a better approach may be to let quality statements be governed by the general rule that they not be false or misleading or by a rule, as some states' directive-style rules include, that prohibits lawyers from making any representation or implication as to quality "which is not susceptible of reasonable verification by the public." ${ }^{188}$ This would be a less restrictive alternative, as required under the Central Hudson test, and yet would also meet the concern expressed by the Bates Court.

f) Firm Names $\square \square$ Lawyers may wish to communicate to the public information about the nature and quality of their practices through direct information in advertisements. As an alternative or supplementary approach, however, lawyers may choose to convey that same type of information through the use of particular names. For years, the names of old private law firms have been associated with particular levels of quality, even after the partners who had provided a firm with its name had long since died. But recently lawyers who are not part of an old firm have attempted to use trade names like the Bankruptcy Clinic, the Louisville Law Clinic, or even the Budget Barrister ${ }^{189}$ to immediately convey the sense of a certain style of practice without waiting a number of years for the reputation of the firm to develop in the manner of the more traditional firms. However, 37 jurisdictions follow ABA Model Code of Pro-

187. 433 U.S. at 383-84.

188. D.C. DR 2-101(C)(3); Fla. DR 2-101(C)(4); Hawaii DR 2-101(C)(3); N.H. DR 2-101(C)(8); N.J. DR 2-101(C)(3); and S.D. DR 2-101(C)(4).

189. See, e.g., Ky. Bar Ass'n Op. No. E-219, in Ky. Bench \& B., Oct. 1979, at 10 (lawyers wanted to call firm "Louisville Law Clinic"); In re Oldtowne Legal Clinic, 400 A.2d 1111 (Md. Ct. App. 1979); N.J. Op. No. 435, 104 N.J.L.J. 305 (1979) (regarding the use of “Budget Barrister"). 
fessional Responsibility DR 2-102(B) prohibiting the use of trade names. ${ }^{190}$

If the Court maintains that its assumption, set forth in Friedman $v$. Rogers, that trade names are "a form of commercial speech that has no intrinsic meaning" 191 is valid, then any reasonable state rationale proffered would be sufficient to hold the regulation against trade names constitutional. But the validity of the Supreme Court's assumption that trade names are meaningless is questionable. Brand names can convey useful information (think about Sears, Rolls Royce) and, as economist Lee Kenneth Benham testified in Friedman, can be useful to the consumer by lessening search costs. ${ }^{192}$ These attributes of trade names would seem to warrant a First Amendment scrutiny beyond the de mimimis protection offered by the Court in Friedman.

The Court has put forth no compelling rationale why a regulation regarding lawyers' use of trade names in public communications should not be analyzed as any other content-based regulation of commercial speech would be. If it were treated as a normal content-based regulation, a prohibition on the use of trade names could not be upheld. For its presumable purpose of preventing people from being misled as to practitioners' identities, such a rule is both underinclusive and overinclusive. First, the rule would be underinclusive, since it allows the use of names of deceased former firm members (which is as misleading as is a trade name) and yet does not allow the use of a name like the Chicago Legal Clinic of Smith and Jones (with Smith and Jones being the actual lawyers running the clinic), which is not misleading as to the identity of the practitioners but would be considered an impermissible trade name. Second, if trade names are assumed to have some inherent meaning, the prohibition against using trade names would most certainly be found unconstitutional under Central Hudson since the regulation is more extensive than is necessary. ${ }^{193}$ The government interest could be met simply by a rule such

190. The rules also prohibit names that are misleading as to the identity of the lawyer or lawyers practicing thereunder. Ala. DR 2-102(B); Alaska DR 2-102(B); Ariz. DR 2-102(B); Ark. DR 2-102 (B); Colo. DR 2-102(B); Conn. DR 2-102(B); Del. DR 2-102(B); Fla. DR 2-102(B) (no trade name, misleading name, nor one that is false, fraudulent, deceptive nor contrary to law); Ga. Std. 9; Hawaii DR 2-102(B); Ind. DR 2-102(B); Iowa DR 2-102(B); Ky. DR 1-102(B); La. DR 2-102(B); Md. DR 2-102(A); Miss. DR 2-102(B); Mo. DR 2-102(B); Mont. DR 2-102(B); Neb. DR 2-102(B): N.H. DR 2-102(B); N.M. DR 2-102(B); N.Y. DR 2-102(B); N.C. DR 2-102(B); N.D. DR 2-102(B); Ohio DR 2-102(B); Okla. DR 2-102(B); Or. DR 2-102(B); Pa. DR 2-102(A); R.I. DR 2-102(B): S.C. DR 2-102(B); Tenn. DR 2-102(B); Tex. DR 2-102(B); Utah DR 2-102(B); Vt. DR 2-102(B); Wash. DR 2-102(B); Wis. DR 2-102(B); and Wyo. DR 2-102(B). For a discussion of other code rules that specifically govern the use of the term "legal clinic" in a firm name see Andrews, supra note 94, at appendix VII.

191. 440 U.S. at 12.

192. Id. at 22 (Blackmun, J., and Marshall, J., concurring in part and dissenting in part).

193. In addition to being judged unconstitutional under the four-part test, prohibitions against the use of trade names would also be suspect for several policy reasons discussed in Central Hudson. 
as that adopted in seven states prohibiting the use of misleading names ${ }^{194}$ or one requiring that the practitioners names be listed along with the trade name.

g) Summary of Content Regulation Analysis $\square \square$ The state codes of professional responsibility contain numerous provisions regarding the permissible content of lawyers' advertisements. These rules govern what lawyers may disclose in advertisements about the identification of legal problems, the backgrounds of lawyers, the characteristics of their firms, the nature of their practices, and the cost and quality of their services. Many of these rules are of doubtful constitutionality. In particular, the rules limiting advertising content to listed information seem open to attack on First Amendment grounds.

The U.S. Supreme Court has already provided a hint that it will not look favorably on a rule following the ABA regulatory approach, such as the rule that Missouri has adopted. In the Bates case, the Court noted that the then-existing ABA code allowed for the disclosure, in the classified section of the telephone directory, of certain listed information (almost identical to the list of items that may be advertised today under the ABA model code ${ }^{195}$ and thus considerably broader than what the Missouri code allows). The list included information such as the lawyer's bar admission, the nature of the lawyer's practice, the fee for an initial consultation, and the names and addresses of references. Nevertheless, the Supreme Court remarked, "We recognize, however, that an advertising diet limited to such spartan fare would provide scant nourishment." ${ }_{196}$ It seems likely that the Supreme Court would find that the regulatory-style rules also provide scant nourishment and thus reject them in favor of a more liberal rule allowing heartier informational fare.

E.g., the Court in Central Hudson summarized Bates and Virginia Pharmacy as holding that "an advertising ban could not be imposed to protect the ethical or performance standards of a profession." 447 U.S. at 564. The Court recalled its language in Bates that "Restraints on advertising . . . are an ineffective way of deterring shoddy work." 'Id. at 565, quoting Bates, 433 U.S. 378. Yet in assuming that trade names were meaningless the Court in Friedman upheld a commercial speech regulation on just such grounds (i.e., an attempt to set quality standards and deter shoddy work). See text at notes 75-77 supra.

The Central Hudson Court also said that it has not in recent years approved a blanket ban on commercial speech unless the expression itself was flawed in some way, either because it was deceptive or related to unlawful activity. Id. at 566 n.9. Yet it did approve of a total ban in Friedman even though the speech at issue was not misleading, merely on the possibility that the speech could be used in a deceptive way.

194. D.C. DR 2-102(B); Hawaii DR 2-102(B); Idaho DR 2-102(B); Kan. DR 2-102(B); Minn. DR 2-102(B); N.J. DR 2-102(B); and Va. DR 2-102(B).

195. The types of information that were permitted to be disclosed in the Yellow Pages under the old DR 2-102(A)(6) (1976) differed from the current ABA DR 2-101(B) regulatory list for advertising in the following ways. The old DR 2-102(A) would not have allowed disclosure of participation in prepaid or group legal services plans or contingent fees, range of fees for services, or an hourly rate. However, it would have allowed the dissemination of certain information that the advertising rule does not, such as posts of honor, section memberships in bar associations, certain hours of availability, and certain references.

196. 433 U.S. at 367. 


\section{B. Regulation of Technique}

The fact that people need more information than they currently have about the law, lawyers, and legal services has been demonstrated by various surveys. ${ }^{197}$ The U.S. Supreme Court in Bates viewed communications from lawyers to the public (in that instance, lawyer advertising) as a way to meet that need. Thus far, this article has discussed the regulations that restrict the content of lawyers' public communications. But the state ethics codes also regulate how lawyers convey information.

In order to assure that the public notices and retains the information conveyed, some attorneys may wish to use the marketing techniques that have been developed by product advertisers. Yet the state advertising rules regulate the format of lawyers' advertisements and thus may prohibit lawyers from using traditional advertising and marketing strategies. These regulations lessen the impact of lawyers' communications in some instances so that they are not sufficiently attention getting, understandable, and memorable and thus prevent the public from comprehending and retaining a message that may contain useful information. Also, by prohibiting lawyers from using the most effective advertising tactics, the rules may deter lawyers from advertising or otherwise communicating information altogether.

Nineteen states have restrictions on how lawyers' advertisements may be presented. ${ }^{198}$ For example, although the advertisement at issue in the

197. See Missouri Survey, supra note 100, at 136; Commentary, supra note 99; Curran, supra note 8.

198. D.C. DR 2-101(C)(4) (no showmanship or self-laudation); Fla. DR 2-101(C)(6) (no showmanship, puffery, self-laudation, or hucksterism, including the use of slogans, jingles, or garish or sensational language or format) and Fla. DR 2-101(E) (incorporates EC 2-11: "The content and format of the legal advertisement should comport with the dignity of the profession and promote public confidence in our legal system. Advertisements which utilize slogans, gimmicks, or other garish techniques are improper"); Ga. Std. 5(B) (for print ads, no photographs, pictorials or other graphic illustrations; only allows black and white ads with type size no greater than $1 / 2 \mathrm{~cm}$. in height), (C)(2) (broadcast commercials must be spoken, unaccompanied by music or sound effects of any description, and must avoid puffery, self-laudation, or hucksterism), and 8(E) (Yellow Page listing must not be in distinctive form or type); Idaho DR 2-101(C)(6) (no showmanship, puffery, self-laudation, or hucksterism, including the use of slogans, jingles, or garish or sensational language or format); Ind. DR 2-101(B) (for print ads, no photograph or other pictorial material; for broadcast commercials, no background music or other sound effects); Iowa DR 2-101(A) (no logos, trademarks, graphics, design work, and pictures) and (B) and (C) (all information must be communicated in words and numbers only; broadcast commercials may use only a single nondramatic voice, not that of the lawyer, with no other background sound; no visual display allowed on television except that allowed in print as articulated by the announcer); Kan. DR 2-101(B) (no drawings, illustrations, animations, portrayals, dramatizations, slogans, music, lyrics, or the use of pictures other than the portrait of the individual lawyer); Miss. DR 2-102(A)(8) (advertisement must be of dignified size and printed in no larger than 12-point type); N.H. DR 2-101(C)(10) (no statement or claim that is intended or is likely to attact clients by use of showmanship, puffery, or hucksterism, including the use of slogans, jingles, or garish or sensational language or format); N.J. DR 2-101(C)(4) (no showmanship); N.M. DR 2-101(D)(2) (no showmanship, puffery, or hucksterism, including the use of slogans, jingles, or garish or sensational language or format); N.C. DR 2-101(B) (no drawings, illustrations, animations, portrayals, dramatizations, slogans, music, lyrics, or pictures, or use of lawyer's voice or portrait); Ohio DR 2-101(B) (no drawings, illustrations, animations, portrayals, dramatizations, slogans, music, lyrics, or the use of pictures, except for ones of the advertising lawyer, or the 
Bates case used as an attention-getting device an illustration of the scales of justice, a number of state advertising rules prohibit the use of logos or various graphic displays such as photographs, pictorials, drawings, illustrations, or designs. Other restrictions include prohibitions on the use of color, music, animations, dramatizations, jingles, slogans, and themes.

Many such rules are apparently motivated by a desire that lawyers' advertisements be dignified. In fact, 26 states specifically require lawyers' advertisements to be "dignified." 199 In a similar vein, the New York rules prohibit lawyers from running advertisements that "cast reflection on the profession as a whole." ${ }^{200}$ Yet this antiquated notion of professional etiquette may impede the use of techniques that allow potential clients to understand and remember necessary information and that allow attorneys to use effective advertising. Two suits recently attacked the code provisions that restrict how lawyers present information in their advertisements. ${ }^{201}$

use of a portrayal of the scales of justice); Okla. DR 2-101(G) (advertisement in print media to general public should not be larger than 10 inches square) and DR 2-101(I) (no signs, symbols, or pictures); Or. DR 2-101(A)(3)(d) (no slogans, jingles, musical themes, dramatic or theatrical imagery, or garish or sensational format or language); R.I. Sup. Ct. Provisional Order No. 11(7) (no photographs, design work, or logos) and (11) ("Advertisements over the electronic broadcast media shall contain no dramatizations, music or lyrics and shall consist solely of a prepared text, consistent with the Order, read by a professional announcer in a dignified manner. Television commercials shall consist solely of a slide presentation, consistent with the Order, accompanied by dignified announcements, read by a professional announcer off-camera. Electronic media advertising shall contain only information appropriate for the print media. Under no circumstances shall any lawyer personally appear on the broadcast media in connection with any commercial advertising"); S.C. DR 2-101(A)(2)(f) (no showmanship, puffery, self-laudation, or hucksterism, including the use of slogans, jingles, or garish or sensational language or format); S.D. DR 2-101(C)(6) (no showmanship, puffery, self-laudation, or hucksterism, including the use of slogans, jingles, or garish or sensational language or format); and Tenn. DR 2-101(I) (television commericals must consist of slides and dignified, prepared text announcements only; neither the lawyer nor his picture may appear in a broadcast ad).

199. Alaska DR 2-101(B); Ariz. DR 2-101(B); Colo. DR 2-101(B); Conn. DR 2-101(B); Del. DR 2-101(B); Fla. DR 2-101(E) and EC 2-11; Ga. Std. 5(B); Ill. DR 2-101(C); Ind. DR 2-101(B); Iowa DR 2-101(B); Kan. DR 2-101(B); Mo. DR 2-101(B); Mont. DR 2-101(B); Neb. DR 2-101(B); Nev. Rule 164(2); N.M. DR 2-101(B); N.C. DR 2-101(B); N.D. DR 2-101(B); Ohio DR 2-101(B); Okla. DR 2-101(B); S.C. DR 2-101(B); Tenn. DR 2-101(B); Utah DR 2-101(B); Wash. DR 2-101(B); W. Va. DR 2-101(B); and Wyo. DR 2-101(B).

The idea that lawyers' advertisements should be dignified is also expressed in Carter v. Lovett \& Linder, Ltd., 425 A.2d 1244, 1245 (R.I. 1981): "We believe that the Supreme Court, in recognizing an attorney's First Amendment right to advertise, never intended to sanction a competitive struggle over which attorney or law firm would receive the advertising industry's accolade for having the biggest, best, and, in the case at bar, most colorful ad in the category reserved for the legal profession." In that case, Lovett and Linder were found to have violated the disciplinary rules by placing an advertisement on the back inside cover of the Yellow Pages telephone directory rather than, as was permitted, in the Yellow Pages themselves. However, in a case involving the same parties, the federal district court in Rhode Island held the rule unconstitutional, saying, "Unfortunately, there appears to be generally no constitutional infirmity in being the biggest, best or most colorful in almost any commercial activity-including advertising." Lovett \& Linder, Ltd. v. Carter, C.A. No. 81-0118, at 21 (D.R.I., Sept. 8, 1981).

200. N.Y. DR 2-101(A).

201. Williams v. North Carolina State Bar, 81-367-civ-5 (E.D.N.C., filed June 12, 1981), is a request for a judgment declaring unconstitutional the North Carolina rules forbidding the use of 
Restrictions on the format of lawyers' communications that may prevent lawyers from communicating information in an attention-getting and understandable way merit scrutiny. The constitutionality of the restrictions on the format of lawyers' public communications should be judged under the time, place, and manner test, ${ }^{202}$ which was alluded to in Bates but not applied since the format of the Bates ad was not being challenged. ${ }^{203}$ This test asks whether the regulation is justified without reference to content, serves a significant governmental interest, and in doing so leaves open ample alternative channels for communication of the information.

The first inquiry is whether the regulation is justified without reference to its content. In Linmark, the regulation at issue was found not to be neutral because it forbade only real estate signs. But the application of this leg of the test to the regulation of lawyers' advertisements is complicated. The codes of professional responsibility for lawyers are not adopted by legislatures but by state supreme courts. These courts do not have jurisdiction over groups other than lawyers and thus it could be argued that their regulations are as neutral as they could conceivably be.

Such an argument, however, is too facile. I would advocate a test where, for a lawyers' advertising regulation to be justified without respect to content, it would either need to be the same as legislatively adopted regulations governing other advertisers or need to be based on some difference between lawyers and other advertisers that required different regulatory handling.

Clearly, the format regulations governing lawyers' communications are not the same as those governing the promotional activities of other groups. Other advertisers, for example, can use color, sound, dramatiza-

graphics in attorneys' print advertisements and forbidding the use by attorneys of their voices or faces in broadcast advertising.

The court in Bishop v. Committee on Professional Ethics \& Conduct, Civ. No. 81-47-D, slip op. at 11 (S.D. Iowa, Aug. 20, 1981), upheld Iowa's prohibition on the use of signs and symbols in lawyers' advertisements. It did so on the basis of its faulty reading of Central Hudson, discussed at note 88 supra. Thus, it held that graphics "can be misleading" and therefore may validly be banned. However, it is difficult to imagine how a picture of the scales of justice or a photo of a lawyer's briefcase (both of which have been used in advertisements in other states) could conceivably be misleading.

202. Some of the restrictions on the technique of presenting advertisements, such as those forbidding graphics, arguably could be considered content restrictions, while others, such as those mandating a particular size for the ad, deal with format alone. I have chosen to analyze all technique restrictions under the time, place, and manner test. However, even with respect to restrictions that could be protected as "content," the result will be the same under the test I am using. Since I will demonstrate that all the technique restrictions are unconstitutional under the time, place, and manner test, they would likewise be unconstitutional under the more protective content analysis of Central Hudson.

203. It is interesting to note, however, that the advertisement at issue in Bates would be improper under a number of state rules because of certain aspects of its format-such as its rhetorical question and its illustration. 
tions, illustrations, rhetorical questions, and other similar techniques in their advertisements. To justify a different standard for the legal profession, lawyers must be sufficiently different from other groups marketing services.

A difference between lawyers marketing services and other professionals (such as pharmacists) marketing particular products was alluded to in Virginia Pharmacy, where the Court noted in dicta that lawyers' advertising of services might have an "enhanced possibility for confusion and deception" as compared to the advertising of products. ${ }^{204}$ However, the Court in Bates did not articulate the differences between lawyers' advertisements and other types of advertisements. Rather, the Bates court indicated that "the conclusion that Arizona's disciplinary rule is violative of the First Amendment might be said to flow a fortiori from" Virginia State Board of Pharmacy. ${ }^{205}$

Although the Bates Court apparently did not find a meaningful distinction between advertising by lawyers and advertising by other groups, Justice Rehnquist, dissenting in Primus, apparently felt that lawyers' activities could be distinguished because a lawyer is "a professional trained in the art of persuasion." ${ }^{206}$ However, that factor alone does not set lawyers apart. Indeed, a lawyer's training in persuasive tactics is probably no greater than that of a door-to-door salesperson or any marketing or advertising expert hired to promote any product or service. Because the format rules create a standard different for lawyers who advertise than for others who advertise, without a sufficient rationale for the distinction, the rules may be vulnerable to attack on the grounds that they are not neutral with regard to content.

If the format rules are found to be neutral, however, the second inquiry that needs to be made under the time, place, and manner test is whether they serve a significant government interest. There has not been any evidence set forth that advertisements in color or with sound or larger than a certain size, for example, are inherently misleading. (If there was such evidence, the Federal Trade Commission would probably long since have cracked down on the product advertisers that use these techniques.) Rather, the government interests that are involved seem to be the interests in protecting the sensibilities of the audience and the image of the profession. ${ }^{207}$ But these are not substantial interests. As noted by the

204. 425 U.S. at 773 n.25.

205. 433 U.S. at 365.

206. 436 U.S. at 441 (Rehnquist, J., dissenting).

207. The state might also advance an argument that certain format restrictions are necessary to prevent people from choosing a lawyer for irrelevant reasons, such as because of his appearance. However, as noted earlier, such an interest is not substantial. See text at notes 130-31 supra. Moreover, some of the items that the state might deem to be irrelevant to choice may be relevant to the consumer. In his interrogatories accompanying his petition to challenge the North Carolina rules 
Court in Carey v. Population Services, the mere offensiveness or embarassing nature of an advertisement does not justify its suppression. ${ }^{208}$ Similarly, the fact that some types of advertising may harm the image of the profession does not justify the prohibition of such advertising. In fact, as the Bates Court pointed out, it is rather disingenuous for lawyers even to think that restrictions on advertisements will cause the public to think that law is not a business.

[W] find the postulated connection between advertising and the erosion of true professionalism to be severely strained. At its core, the argument presumes that attorneys must conceal from themselves and from their clients the real-life fact that lawyers earn their livelihood at the bar. We suspect that few attorneys engage in such self-deception.

$\cdot \cdot \cdot$

.. . Since the belief that lawyers are somehow "above" trade has become an anachronism, the historical foundation for the advertising restraint has crumbled. ${ }^{209}$

Thus the format regulations are unconstitutional since they do not serve a significant government interest.

\section{Media Rules}

Whether a lawyer's communication effectively reaches its target audience and conveys its message in an understandable and memorable way depends not only on the content and format of the message but also on the medium in which it is conveyed. Every medium has its own strengths and weaknesses. Advertising in a newspaper or other print media allows a lawyer to present a large quantity of explanatory material and permits the

prohibiting the use of an attorney's picture or voice, Williams asked the state bar why "it would not be preferable to have an attorney appear in his own television advertisements, so that the viewers considering calling on him for legal services which involve the use of his voice, personality and face, could be initially exposed to his voice, personality and face rather than that of a television personality." Williams v. North Carolina State Bar, 81-367-civ-5 (E.D.N.C., filed June 12, 1981).

In Bishop v. Committee on Professional Ethics \& Conduct, Civ. No. 81-47-D (S.D. Iowa, Aug. 20,1981 ), an attorney challenged various aspects of the Iowa ethics code rules relating to advertising. The attorney wished to run a picture of himself in the advertisement to convey that he was a black attorney. The court conceded that "such information can serve a useful purpose. Many persons, especially many in the segment of the public to which lawyer advertising is primarily directed, are apprehensive about going to a lawyer and prefer, as a means of somewhat allaying their apprehensions, to seek out a lawyer with whom they can identify." Id. at 11 . However, even though the court felt that "[a] photograph of a lawyer would usually accurately inform the viewer about his race" (id. at 24 n.6), the court upheld the ban on graphics and instead granted the lawyer the right to mention in his ads the fact that he was black. See note 201 supra.

208. Carey v. Population Servs. Internat'l, 431 U.S. 678, 701 (1977). Moreover, there is little evidence that letting lawyers have a full panoply of advertising techniques at their disposal will result in extensive use of undignified advertisements. Hellman, supra note 87, at $558 \mathrm{n} .292$, points out that banks, stockbrokers, and churches advertise without a loss of dignity. "Why isn't the market place an adequate regulator of 'dignity and professionalism' in advertising?" Asks Hellman, "If such ads are so unworthy, what client would be attracted by them?" Id. at 563 n.317.

209. 433 U.S. at $368,371-72$. 
reader to consider the information carefully and to reread it. However, because many people in the United States either do not know how to $\operatorname{read}^{210}$ or choose to get their news from broadcast sources, a lawyer's broadcast commercial has the potential for bringing information to a wider range of people. The poor are one large group who, for the above reasons, tend to rely more on broadcast media than printed sources for obtaining information. ${ }^{211}$

Within the mass media, there are also a variety of ways lawyers can reach particular audiences. An attorney who practiced corporate law could advertise in a business trade journal rather than in a publication whose readers included a large number of people who would never need corporate legal services. To a certain extent, appeals to people in a particular audience segment can be accomplished by designing an advertisement to attract that type of person. But it can be accomplished even more effectively by picking a medium that is targeted primarily to that type of person.

In addition to the potential the various forms of mass media offer for conveying information to people about the law, lawyers and legal services, and for effectively marketing a lawyer's services, more personalized approaches can also serve those purposes. Direct mail and in-person contact, for example, present the chance for lawyers to communicate to potential clients at the time when they most need information about legal services. The latter form of personalized contact, however, presents problems, because the clients who are in need of legal services may also be in a physical or emotional state that makes it very difficult for them to make an intelligent choice of a lawyer.

\section{Mass Media Regulations}

In Bates, the ad at issue appeared in a newspaper, but the Court noted that "the special problems of advertising on the electronic broadcast media will warrant special attention."212 Some state supreme courts have used that statement as support for banning broadcast advertising. Although 38 jurisdictions allow print, radio, and television advertisements, ${ }^{213} 2$ allow

210. Because of widespread "functional illiteracy," radio and television are the only methods of informing many members of the public. American Bar Association, Commission on Advertising, Report to the House of Delegates (paper, 1978).

211. R.H. Bruskin Associates, Survey for the Television Bureau of Advertising, Adults: Percent Reached and Time Spent Yesterday in Minutes with Major Media (typed table 1980).

212. 433 U.S. at 384.

213. Alaska DR 2-101(B); Ariz. DR 2-101(B); Ark. DR 2-101(B); Cal. DR 2-101; D.C. DR 2-101; Fla. DR 2-101; Ga. Std. 5(C); Hawaii DR 2-101; Idaho DR 2-101; Ill. DR 2-101; Iowa DR 2-101(B); Kan. DR 2-101(B); Ky. Rule 3.135; La. DR 2-101; Me. Rule 3.9(a); Md. DR 2-101(A); Mass. DR 2-101; Mich. Sup. Ct. Orders effective Mar. 15, 1978, and Feb. 2, 1979; Minn. DR 2-101(A); Mont. DR 2-101(B); Neb. DR 2-101(B); Nev. Rule 164(2); N.H. DR 2-101; N.Y. DR 2-101; N.C. DR 2-101(B); N.D. DR 2-101(B); Ohio DR 2-101(B); Or. DR 2-101(A); Pa. DR 2-101(A); R.I. Sup. Ct. Provisional Order No. 11(1); S.C. DR 2-101(D); S.D. DR 2-101(A); Tenn. DR 2-101(B); Utah Sup. 
print and radio advertisements only, ${ }^{214}$ and 10 allow print advertisements only. ${ }^{215}$ Other jurisdictions restrict the use of handbills ${ }^{216}$ and billboards. ${ }^{217}$

The Bates Court referred to "special problems of advertising on the electronic media," but that reference in itself is not support enough for banning broadcast commercials. Traditionally, the special problems created by broadcasting have been due to the limitations on the number of frequencies. The Supreme Court has noted that, unlike the print media, the broadcast media are "inherently . . . not available to all." 218 But this fact provides no reason for prohibiting lawyers' broadcast commercials. Indeed, "no rational distinction can be made between radio and television on the one hand and the press on the other in affording the constitutional protection contemplated by the First Amendment."219 Thus, any restriction on broadcast advertising must be closely scrutinized to determine whether it is in keeping with the First Amendment.

The mass media rules are clearly regulations governing the manner of commercial speech. Thus, they, like the format rules, should be analyzed under the three-part test that provides that such regulations are permissible only if they are justified without respect to content, serve a significant government interest, and leave open ample alternative channels for communication of the information. ${ }^{220}$ Some proponents of format restrictions on lawyers' advertisements have erred in the way they have applied this test. For example, they have given as a justification for a ban on certain communications media the fact that other channels of communica-

Ct. Order No. 16347; Va. DR 2-101(A); Wash. DR 2-101(B); and Wis. Sup. Ct. Order of April 30, 1979. The Texas provision gives no guideline regarding broadcast advertising; it merely suspends the operation of its old advertising rule "to the extent that it conflicts with . . Bates." Tex. Sup. Ct. order of Dec. 13, 1978.

214. Ind. DR 2-101(B) and Wyo. DR 2-101(B).

215. Ala. DR 2-102(A)(7)(d); Conn. DR 2-101(B); Del. DR 2-101(B); Miss. DR 2-102(A)(8); Mo. DR 2-101(B); N.J. DR 2-101(D); N.M. DR 2-101(B); Okla. DR 2-101(B); Vt. DR 2-101(D); and W. Va. DR 2-101(B).

216. See, e.g., Ala. DR 2-102(A)(7)(d).

217. See, e.g., Ohio DR 2-101(B). This prohibition against billboard advertising was upheld in Law Firm of Calig \& Waterman v. Supreme Court, No. $79-394$ (Iowa Sup. Ct., June 8, 1979), cert. denied, 48 U.S.L.W. 3309.

218. NBC v. United States, 319 U.S. 190, 226 (1943); Red Lion Broadcasting Co., Inc. v. FCc, 395 U.S. 367,390 (1969).

219. Rosenbloom v. Metromedia, Inc., 415 F. 2d 892, 895 (3d Cir. 1969), aff'd, 403 U.S. 29 (1971).

220. Justices Powell and Stewart in their separate opinion in Bates refer to the use of the time, place, and manner test in judging the constitutionality of the use of certain media:

The Court speaks specifically only of newspaper advertising, but it is clear that today's decision cannot be confined on a principled basis to price advertisements in newspapers. No distinction can be drawn between newspapers and a rather broad spectrum of other means-for example, magazines, signs in buses and subways, posters, handbills, and mail circulations. But questions remain open as to time, place, and manner restrictions affecting other media, such as radio and television.

433 U.S. at 402 n.12. 
tion exist for the information. ${ }^{221}$ However, the mere fact that one part of the test is satisfied is not sufficient; and when the other two parts of the test are considered, it is clear that the mass media restrictions are unconstitutional.

In applying the time, place, and manner test, the analysis whether the regulations governing lawyer advertising are content neutral is the same as that discussed earlier with respect to format regulations. ${ }^{222}$ However, the media regulations reflect different government interests than do the format regulations and thus deserve in-depth scrutiny here.

An analysis of the characteristics of the media prohibited under various rules shows that these media are not so potentially harmful as to give rise to a substantial state interest warranting their suppression. Consider the various characteristics that a state might find troublesome. The state would probably advance the same argument that it did to justify a suppression of print media advertising, namely, that allowing the use of certain media would adversely affect professionalism, the quality of services, and the administra ion of justice; that it would have undesirable economic side effects; that it would be inherently misleading; and that it would create difficulties in enforcement. With respect to these arguments, which are all rejected in Bates, there is no reason to believe the economic effects or the effects on professionalism, quality, or judicial administration of media like radio, television, handbills, or billboards would be greater than that of the print media. ${ }^{223}$ Thus, such arguments

221. Counsel for the Missouri Bar Advisory Committee makes this flawed argument in his brief to the U.S. Supreme Court in In re R.M.J. He tries to justify the rule against direct mailings by stating the three parts of the time, place, and manner test, then states that the rule is justified since it allows for ample alternative channels of communication. Respondent's Brief, In re R.M.J., at 13.

An even grosser error in application of the time, place, and manner test was made in Bishop, Civ. No. 81-47-D, (S.D. Iowa, Aug. 20, 1981). When asked to rule on the constitutionality of the geographic limitations on advertising, the court did not even apply the three-part test. Instead, citing Bates, it made the conclusory statement "[t]hose limitations are clearly 'reasonable restrictions on the . . . place . . of advertising." Id. at 21 (ellipses in original).

An appropriate use of the time, place, and manner test was made by the federal district court in Rhode Island in Lovett \& Linder, Ltd. v. Carter C.A. No. 81-0118, at 17-21 (D.R.I., Sept. 8, 1981). The lawyer advertising rule at issue in the case prohibited lawyers from advertising on the inside back cover of the Yellow Pages directory. The court held that "[a]part from whatever alternative channels are left open," an inquiry must be made into whether a significant governmental interest exists to justify the regulation. Id. at 18 . In the Rhode Island case, the prohibition was struck down since it did not serve such an interest.

222. See text following note 203 supra.

223. Despite the fact that the Bates court did not find the maintenance of an aura of professionalism to be a sufficient state interest to ban print advertising, the court in Bishop, Civ. No. 81-47-D, at 17-18 (S.D. Iowa, Aug. 20, 1981), upheld a restriction against flyers, leaflets, billboards, and phone book covers in order to preserve professionalism by minimizing commercialization of the legal profession. In that same opinion, however, the court held unconstitutional the provision prohibiting lawyer advertisements in publications other than newspapers and periodicals of general circulation. With respect to that rule, the court found no sufficient governmental interest. Id. at 17. In addition, the court struck down the state's prohibition on the use of direct mail, specifically rejecting the "overcommercialization" argument. Id. at 20. These varying thrusts are difficult to reconcile, since, even within the court's analytic framework, it would appear just as likely that a leaflet would be tasteful as that a letter would. 
do not provide a sufficient government interest to justify the prohibition against alternative mass media.

However, it may be that alternative mass media do present a greater risk of being misleading and a greater difficulty of enforcement than does print media advertising. For example, it could be argued that media like radio, television, and billboards are more misleading than print because, in general, an advertisement in these media contains less information than does a print advertisement. In addition, the fleeting nature of a broadcast advertisement can make it more difficult for an audience member to comprehend the message clearly. Moreover, it could be argued that, since the evidence indicates that broadcast advertisements go to a less literate audience than do print advertisements, there is a greater inherent likelihood that broadcast advertisements will mislead.

However, it is doubtful that any of these arguments would convince the U.S. Supreme Court, since they are all based on an allegation that no information is better than some truthful information, an assertion that the Court has consistently rejected in the commercial speech cases. In Virginia State Board of Pharmacy, for example, the Court viewed unfavorably a regulation in which "the State's protectiveness of its citizens rest[ed] in large measure on the advantages of their being kept in ignorance." 224 The Court favored an alternative that "is to assume that this information is not in itself harmful, that people will perceive their own best interests if only they are well enough informed, and that the best means to that end is to open the channels of communication rather than to close them." 225 The Bates Court likewise stated, "If the naivete of the public will cause advertising by attorneys to be misleading, then it is the bar's role to assure that the populace is sufficiently informed as to enable it to place advertising in its proper perspective." ${ }^{226}$ Although it is possible that some lawyers may try to use broadcast commercials in a misleading or fraudulent way, the Supreme Court has already pointed out in Bates that "the appropriate response to fraud is a sanction addressed to that problem alone, not a sanction that unduly burdens a legitimate activity." 227

The argument that most closely approaches a substantial government interest in prohibiting media other than the print media is one asserting a difficulty in enforcement. There is no doubt that it is more time consuming and difficult to monitor advertisements over the airwaves and via handbills ${ }^{228}$ than it is to monitor print media advertisements. But it can hardly be suggested that this governmental interest is substantial enough

224. 425 U.S. 748,769 (1976).

225. Id. at 770, cited in Bates, 433 U.S. at 365.

226. 433 U.S. at 375.

227. Id. at 375 n.31.

228. It is questionable whether it is sufficiently more difficult to monitor billboards since they generally stay at a particular location for a long time. 
to warrant suppression of the entire broadcast and handbill media, particularly since the purportedly substantial interest can be easily and adequately remedied by requiring that attorneys retain copies of their advertisements in all media for a certain period of time. ${ }^{229}$

The mass media restrictions would probably also be constitutionally infirm on the grounds that they do not leave open ample alternative channels of communication. For example, prohibitions against broadcast advertising prevent an attorney's message from reaching the many people who do get their information through the broadcast rather than the print media. In addition, it is questionable whether an alternative that is much more costly is in fact an ample alternative. For example, a storefront legal clinic lawyer who wanted to serve neighborhood clients might argue that expensive advertisements in the print or broadcast media that reach the entire city (or beyond) are not an ample alternative to less costly and more highly targeted advertising through handbills distributed in the neighborhood or on a billboard located near the office. ${ }^{230}$

\section{Private Promotional Communications}

In addition to the provisions of the state advertising rules that prevent lawyers from using certain types of mass media, provisions of the various state solicitation rules restrict lawyers' private promotional activities. For example, at least 38 states prohibit direct mailings to potential clients. ${ }^{238}$ This rule is so stringent that, for example, according to a North Carolina ethics opinion, the mailing of an advertisement, even when the ad itself complies with the ethical rules, would be improper. ${ }^{232}$ The mailing rules include exceptions for communications to friends, family, and, in some cases, current and past clients. Although direct mailings have been lumped together with in-person conduct as solicitation under most state codes, direct mail is considered by marketing experts to be an advertising medium.

As in the case of ethics code rules governing advertising, the disciplinary

229. The ABA model code and the state codes contain various provisions designed to aid disciplinary authorities in monitoring advertisements. Some of these provisions are designed to assure that the authorities have copies of the lawyers' advertisements, or at least have access to copies of them. See, e.g., Kentucky, where a lawyer must mail a copy of an advertisement (be it a print or broadcast or direct mail communication) to the state bar association simultaneously with the advertisement's publication. Ky. Rule 3.135 (if the communication was by direct mail, the lawyer must also send the bar association "a list of all the persons or firms to whom it is being or will be sent or delivered"').

230. Although I have chosen to analyze the mass media restrictions under the traditional time, place, and manner test, the restrictions would also be found unconstitutional under the Central Hudson test as well, both because the government interests advanced are not substantial enough and because, with respect to enforcement (where there is a conceded governmental interest), the rule prohibiting the use of certain media is more restrictive than is necessary to serve the interest.

231. Andrews, supra note 94, at 63 .

232. N.C. Op. CPR 176 (July 14, 1978), N.C. St. B.Q., No. 3, 1978, at 26. 
rules governing solicitation will undoubtedly need revision as they are subjected to constitutional scrutiny. The promotion of legal services by a lawyer directly or through an intermediary may no longer be prohibited merely because it is labeled "solicitation." As the U.S. Supreme Court pointed out in Bigelow v. Virginia, "Regardless of the particular label asserted by the State-whether it calls speech 'commercial' or 'commercial advertising' or 'solicitation'-a court may not escape the task of assessing the First Amendment interest at stake and weighing it against the public interest allegedly served by the regulation." 233

Like the restriction on mass media analyzed earlier, the restrictions on direct mail communications to potential clients should be subjected to the time, place, and manner test, inquiring whether the regulation can be justified without respect to content, whether the government interest is substantial, and whether the regulation leaves open ample alternative channels for communication.

The government interests traditionally advanced to justify a ban on solicitation are prevention of: the fomentation of litigation, subornation of perjury, harassment suits, exorbitant legal fees, invasion of privacy, overreaching, undue influence, intimidation, and enforcement problems. ${ }^{234}$ However, the first three of these problems do not seem to be peculiarly linked with solicitation. Moreover, they were rejected as insufficient to justify a ban on speech in the Bates case, since the suppression of the speech could not directly advance those interests. ${ }^{235}$ Similarly, high legal fees do not seem peculiarly linked to private promotional communications nor does a rule prohibiting such communications directly advance an interest in lowering fees.

The other potential harms of invasion of privacy, overreaching, undue influence, or intimidation do not seem to be closely linked to direct mail communications. As the U.S. Supreme Court pointed out in Consolidated Edison v. Public Service Commission, the letter's recipient "may escape exposure to objectionable material simply by transferring [it] from envelope to wastebasket." ${ }^{236}$ Similarly, when the New York Court of Appeals in Koffler v. Joint Bar Grievance Committee held a bar on direct mail by attorneys to be unconstitutional, it noted that the risk of invasion of privacy and the possibility of overbearing persuasion, both of which were condemned in Ohralik, are "not sufficiently possible in mail solicitation to justify banning it." ${ }^{237}$ The problem of enforcement with respect

233. 421 U.S. 809,826 (1975).

234. See, e.g., Ohralik, 436 U.S. at 461 ; Comments, supra note 51.

235. 433 U.S. at 350.

236. Consolidated Edison Co. v. Public Serv. Comm'n, 447 U.S. 530, 542 (1980).

237. Koffler v. Joint Bar Ass'n, 51 N.Y.2d 140, 149, 412 N.E.2d 927, 933, 432 N.Y.S.2d 872, 877 (1980). 
to a letter does not appear to be substantial since, as in the case of a print ad, the person who is solicited has a copy of the lawyer's communication. A requirement that a mailing be filed with the bar association or the court might also be adopted to aid the monitoring process. ${ }^{238}$

Furthermore, although it may appear offensive to mail a letter to someone who has suffered some loss (the death of a spouse, an injury in an auto accident) or to try to solicit legal business, the mere fact that a communication may be offensive to some does not warrant its suppression. ${ }^{239}$

An additional rationale for holding the ban on direct mail unconstitutional under the time, place, and manner test is that such a ban does not leave a lawyer with ample alternative channels of communication. None of the mass media communications channels allow the lawyer to reach only the people who are in need of legal services. ${ }^{240}$ In addition, as the New York Court of Appeals implied in Koffler, direct mail may be comparatively less costly and more effective and thus the alternatives will not be ample. ${ }^{241}$

\section{CONCLUSION}

This article has shown how the advertising, specialization, and solicitation rules of the state codes of professional responsibility regulate the content, format, and media of lawyers' promotional communications to

238. Such a requirement was suggested by the New York Court of Appeals in Koffler, id. at 150, 412 N.E.2d at 933, 432 N.Y.S.2d at 878, and by the Kentucky Supreme Court in Kentucky Bar Ass'n v. Stuart, 568 S.W.2d 933 (Ky. 1978), in its decision holding unconstitutional a ban on direct mail promotional communications by lawyers. The federal district court in Bishop, Civ. No. 81-47-D, slip op. at 21, (S.D. Iowa, Aug. 20, 1981), also held that rules prohibiting direct mail "violate [an attorney's] First Amendment right of commercial speech." The court held that the state interest in preventing deception could be met by a less restrictive alternative than a total ban-namely, a filing requirement such as that suggested by the New York and Kentucky courts. Id. In addition, the court recognized that "in the average home some anxiety might be generated by the arrival in the mail of an envelope from a lawyer's office" and that "[p]rohibition of direct mailing would prevent such feelings of anxiety." Nevertheless, the Iowa court held that such a prohibition is far more extensive than necessary since "a requirement that there be printed or stamped on the envelope the words "Advertising Content' would suffice." Id. at 20.

239. See text at note 33 supra.

240. In fact, one grievance committee pointed out, "To prohibit a lawyer from selecting as the recipients of a communication those who might be most in need of a lawyer's services is to suck much of the meaning out of the Bates rationale" regarding the importance of informing people about the availability, nature and prices of legal services. Professional Guidance Comm. Releases Two Recent Opinions, Legal Intelligence, Sept. 24, 1980, at 1, citing Bates, 433 U.S. at 364.

241. 51 N.Y.2d at 150,412 N.E.2d at 934,432 N.Y.S.2d at 878 . The application of the time, place, and manner test demonstrates that a lawyer's direct mail communication to a client may not constitutionally be prohibited. The same result would be reached under the Central Hudson test because the governmental interests advanced are not substantial enough, the rules do not directly advance these interests, and even if the interests are considered substantial, there are less restrictive means of achieving them. The Court in Koffler used the Central Hudson test to declare unconstitutional the rule prohibiting the use of direct mail. 
the public. In many instances, these rules not only are ill-suited to the public's needs but also infringe on attorneys' First Amendment commercial speech rights.

The U.S. Supreme Court currently has before it In re R.M.J., the case of a Missouri attorney who was subject to discipline because his promotional activities did not comply with the Missouri code of professional responsibility. His promotional communications were considered improper because they included information that was not permissible under Missouri's regulatory-style advertising rule, described his practice according to terms not sanctioned under the state's specialization rule, and entailed a mailing of an office announcement to two potential clients who were strangers to him in violation of the solicitation rule. The rules at issue in In re R.M.J. impede the public from getting necessary information and reduce the effectiveness of lawyers' attempts to communicate with potential clients. In addition, the teachings of the commercial speech cases from Virginia State Board of Pharmacy to Central Hudson indicate that these rules, like many others discussed in this article, are unconstitutional infringements on attorneys' First Amendment rights. 
HeinOnline -- 1981 Am. B. Found. Res. J. 10221981 